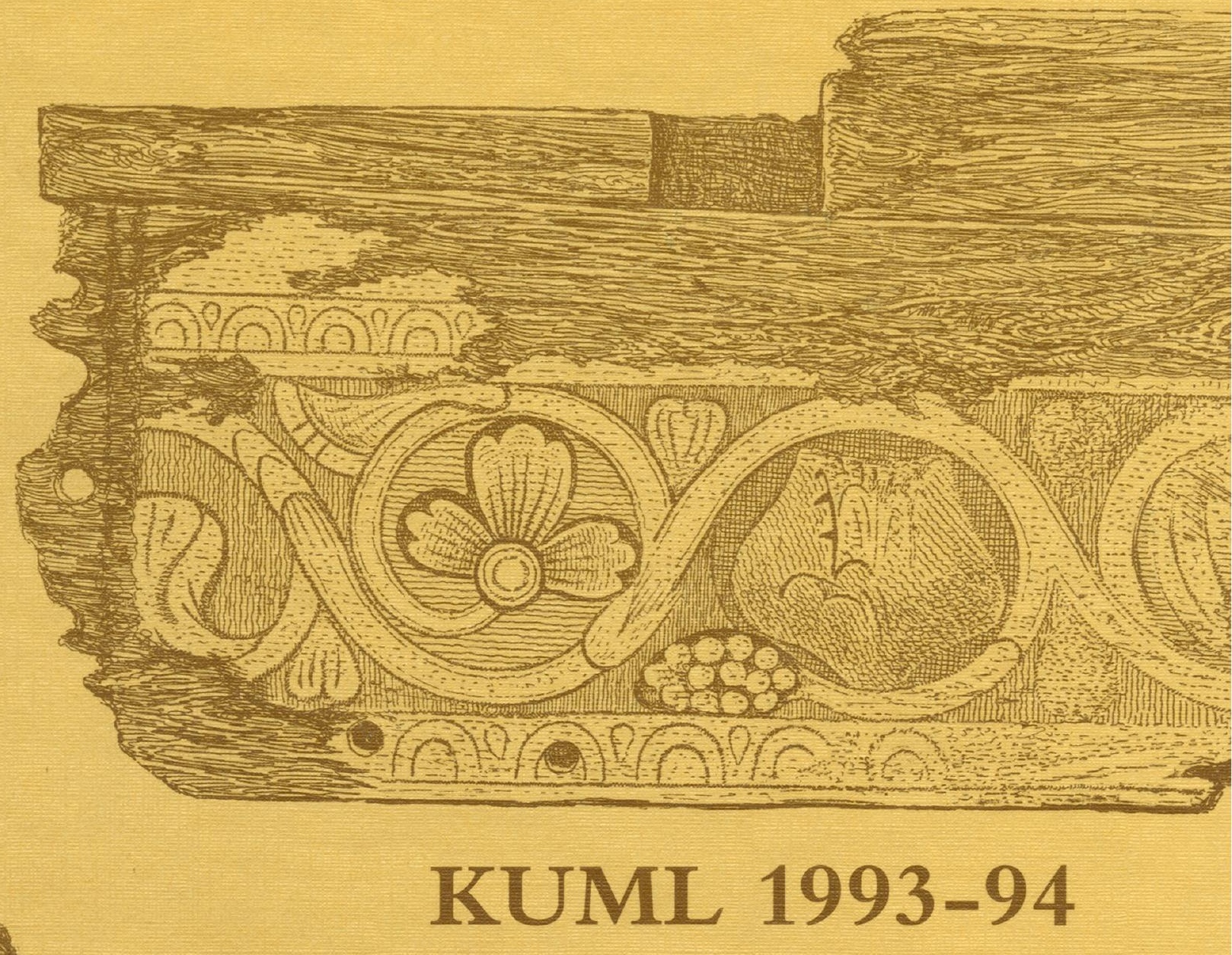




\section{KUML 1993-94}

Årbog for Jysk Arkæologisk Selskab

With summaries in English 
Redaktion: Hans Jorgen Madsen, Poul Kjarum og Birgit M. Rasmussen

Redaktionsudvalg:

Steen W. Andersen, Haderslev

Jens Henrik Bech, Thisted

Steen Hvass, Vejle

Stig Jensen, Ribe

Erik Johansen, Aalborg

Carsten Paludan-Müller, Randers

Ole Schiorring, Horsens

Lay-out og omslag: Jørgen Mührmann-Lund

Grafisk tilrettelagggelse: Elsebet Morville

Tryk: Narayana Press

Skrift: Bembo 11/12

Papir: $115 \mathrm{~g}$ Artik Silk

Copyright 1996 by Jysk Arkaologisk Selskab

ISBN 87-7288-585-8

ISSN 0454-6245 


\section{Indhold/Contents}

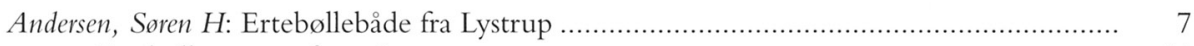

Ertebølle canoes from Lystrup ....................................................................... 36

Ebbesen, Klaus: En jættestue ved Fjersted, Sydvestjylland......................................... 39

A Passage Grave at Fjersted, SW Jutland ................................................... 85

Hansen, Mogens: Træbyggede gravkister fra Enkeltgravskulturen og Senneolitikum ........... 87

Wooden burial cists from the Single Grave Culture and the Late Neolithic .............. 145

Nilsson, Torben: Store Tyrrestrup

En vendsysselsk storgård med bronzedepot fra ældre bronzealder............................ 147

Store Tyrrestrup. A large Early Bronze Age farmstead with bronze hoard .............. 153

Anne-Lonise Haack Olsen og Jens-Henrik Bech. Med bidrag af Svend Th. Andersen,

Pia Bennike, Kjeld Christensen og David Earle Robinson: Damsgård

En overpløjet høj fra ældre bronzealder per. III med stenkiste og ligbrændings-

grube .....

Damsgård. A ploughed-over barrow from Early Bronze Age Per. III with

stone cist and pyre-pit.

Aase Gyldion Andersen: Frugtbarhedsofringer i Sydvestfyns ældre jernalder

Private eller kollektive ofringer?

Fertility Sacrifices in the Early Iron Age of SW Funen. - Private or Collective?..... 210

Torben Egeberg Hansen: Et jernalderhus med drikkeglas i Dejbjerg, Vestjylland .................. 211

Drinking Glasses from an Iron Age settlement from Dejbjerg, West Jutland.............. 237

Mette Iversen og Bjarne H. Nielsen: Brandstrup III.................................................... 239

Grave fra yngre romersk jernalder

Brandstrup III. Graves from the Late Roman Iron Age...................................... 250

Anne Hedeager Krag: Smykkefundet fra Lerchenborg ............................................. 251

Østlige forbindelser i vikingetid

The Lerchenborg Ornaments. Eastern connections in the Viking Age ................ 261

Jens Jeppesen og Holger Schmidt: Rekonstruktion af stavkirken fra Hørning ....................... 263

The reconstruction of the stave church at Hørning ............................................... 275

Bruno Frohlich, Henrik Hjalgrim, Judith Littleton, Niels Lynnerup og Birgitte Sejrsen:

Skeletfundene fra Skt. Peders sognekirkegård i Randers ......................................... 277

Skeletal remains from St. Peder's parish church in Randers .................................. 287

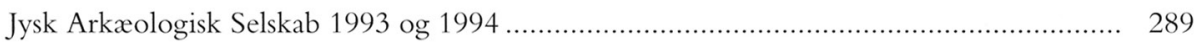




\title{
Damsgård \\ En overpløjet høj fra ældre bronzealder per. III med stenkiste og ligbrændingsgrube
}

\author{
Af Anne-Louise Haack Olsen og Jens-Henrik Bech \\ Med bidrag af Svend Th. Andersen, Pia Bennike, Kjeld Christensen og \\ DAVID EARLE ROBINSON
}

Få steder i landet er der i tidens løb fremdraget så mange gravfund fra ældre bronzealder som $\mathrm{i}$ Thy. Vores viden om gravformer og gravudstyr i denne periode er som følge heraf ganske omfattende, og det er sjældent, at nye fund ændrer væsentligt ved det eksisterende billede.

En nyligt afsluttet undersøgelse af en overpløjet høj ved Damsgård i Sønderhå sogn, Hassing herred i Thy, foretaget af Museet for Thy og V. Hanherred, har imidlertid bidraget med en væsentlig nyhed: Fundet af en brandgrav fra per. III af ældre bronzealder med den tilhørende ligbrændingsgrube (1).

Eksemplet fra Damsgård er det første sikkert erkendte i dansk ældre bronzealder, men en gennemgang af udgravningsberetninger i museets arkiv samt af beskrivelser i litteraturen viser, at der ikke er tale om et enkeltstående tilfælde. Det viser sig, at samtidige grave med ligbrændingsgruber i flere tilfælde kan påvises både $\mathrm{i}$ og uden for Thy. I alt kendes der fem eksempler fra Thy (fig. 1) og to fra øen Sild i Vadehavet. De vil alle blive fremlagt og diskuteret i det følgende.

\section{Damsgård}

Topografi og andre gravfund $i$ området

Gravhøjen ved Damsgård ligger på en $1 \mathrm{~km}$ bred landtunge, der mod øst og syd er begrænset af Hørsted Å's slyngede løb samt af engene omkring åen. Mod vest er landtungen afgrænset af et op til $400 \mathrm{~m}$ bredt mose- og engstrøg kun $1 \mathrm{~km}$ fra Ove Sø (fig. 2).

Højen er en del af en mindre gruppe bestående af 9 høje, hvoraf kun en enkelt ikke er sløjfet idag. Fra én af disse høje stammer et ældre gravfund med bl.a. en bøjlenål fra ældre bronzealder samt forskellige genstande fra yngre bronzealder (2). Nogle hundrede meter syd for højgruppen blev i 1905 på sydspidsen af landtungen fundet en anden grav fra ældre bronzealder i en mindre høj (3). Andre gravfund kendes ikke i den umiddelbare nærhed af højen fra Damsgård.

\section{Forhistorien}

Efter høsten 1992 gravede ejeren af Damsgård, gdr. Knud Kvejborg, og hans søn ned til nogle sten, som de ved pløjning tidligere på året var blevet opmærksomme på. Året forinden var en større, flad sten blevet pløjet op sammesteds. Efter at have frilagt stenene, der viste sig at danne en mindre stenkiste, indstillede finderne arbejdet og kontaktede museet. 


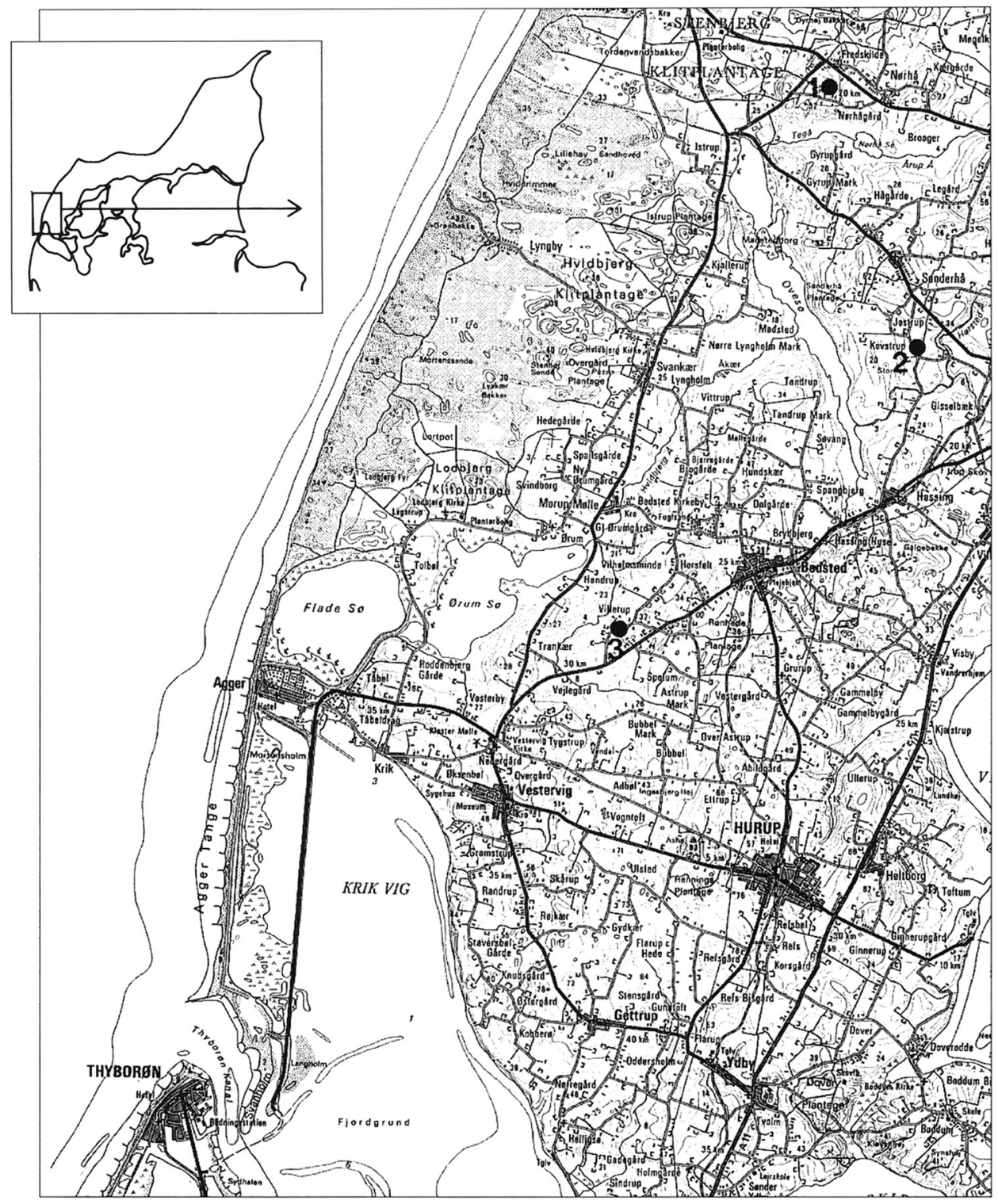

Fig. 1. Ligbrændingsgruber fra ældre bronzealder i Thy. 1: Nørhå, 2: Damsgård, 3: Villerup. (C) Kort og Matrikelstyrelsen (A.256-96).

Pyre pits from the Early Bronze Age in Thy. 1: Nørhå, 2: Damsgård, 3: Villerup.

Umiddelbart herefter iværksattes undersøgelsen af kisten, og da kanten af et større fyldskifte med rødbrændt aske blev iagttaget lige nord for denne, blev feltet udvidet. Herved fremkom ligbrændingsgruben, der fremstod som et mandslangt, meget tydeligt fyldskifte (fig. 3). Hele højen med randstenskæder m.v. blev efterfølgende afdækket i 1993 som led i Thy Projektet (4). 


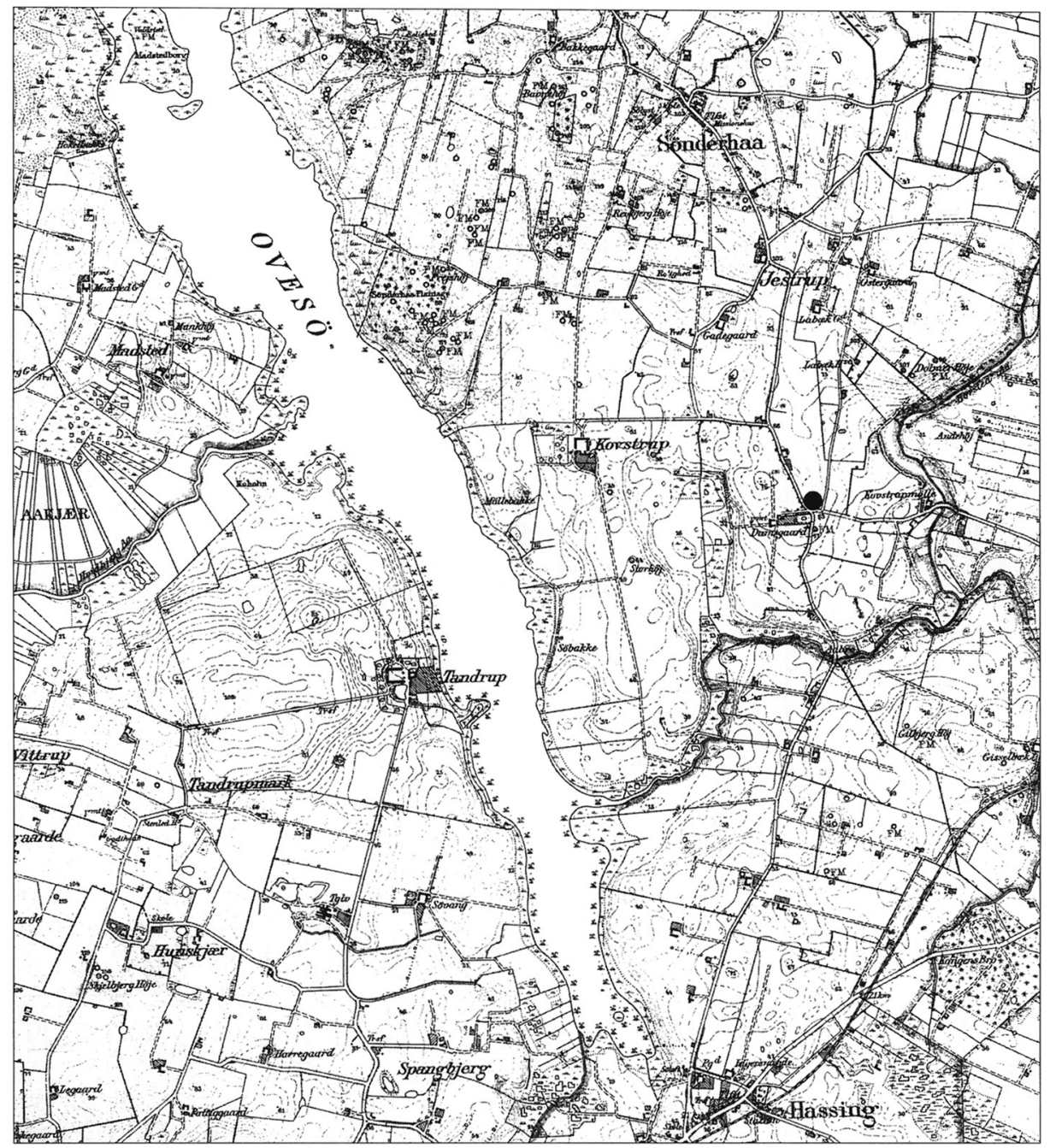

Fig. 2. Udsnit af målebordsblad opmålt 1882-1883 med den overpløjede høj ved Damsgård angivet. (C) Kort og Matrikelstyrelsen (A.256-96).

Section of a map surveyed in 1882-1883 showing the ploughed-over burial mound at Damsgård.

\section{Højen}

Udgravningen viste, at højen havde to faser, hvor den yngste kun var repræesenteret ved enkelte bevarede randsten og stenspor, som tilsammen dannede den ene halvdel af højfoden (fig. 4-5). Dyrkning i nyere tid havde allerede fjernet sporene efter den anden halvdel. Efter de bevarede rester at dømme har højen i fase 2 haft en diameter på ca. $15 \mathrm{~m}$. Ingen spor efter den tilhørende grav blev fundet, men sandsynligvis tilhører fase 2 , ligesom fase 1, ældre bronzealder, idet højbyggeriet i Thy stort set ophører med overgangen til yngre bronzealder.

Af anlæg yngre end højen blev kun fundet en lille ØSØ-VNV orienteret jordfæestegrav ca. 1,10x0,6 m med en tenvægt af ler og en jernkniv som eneste 

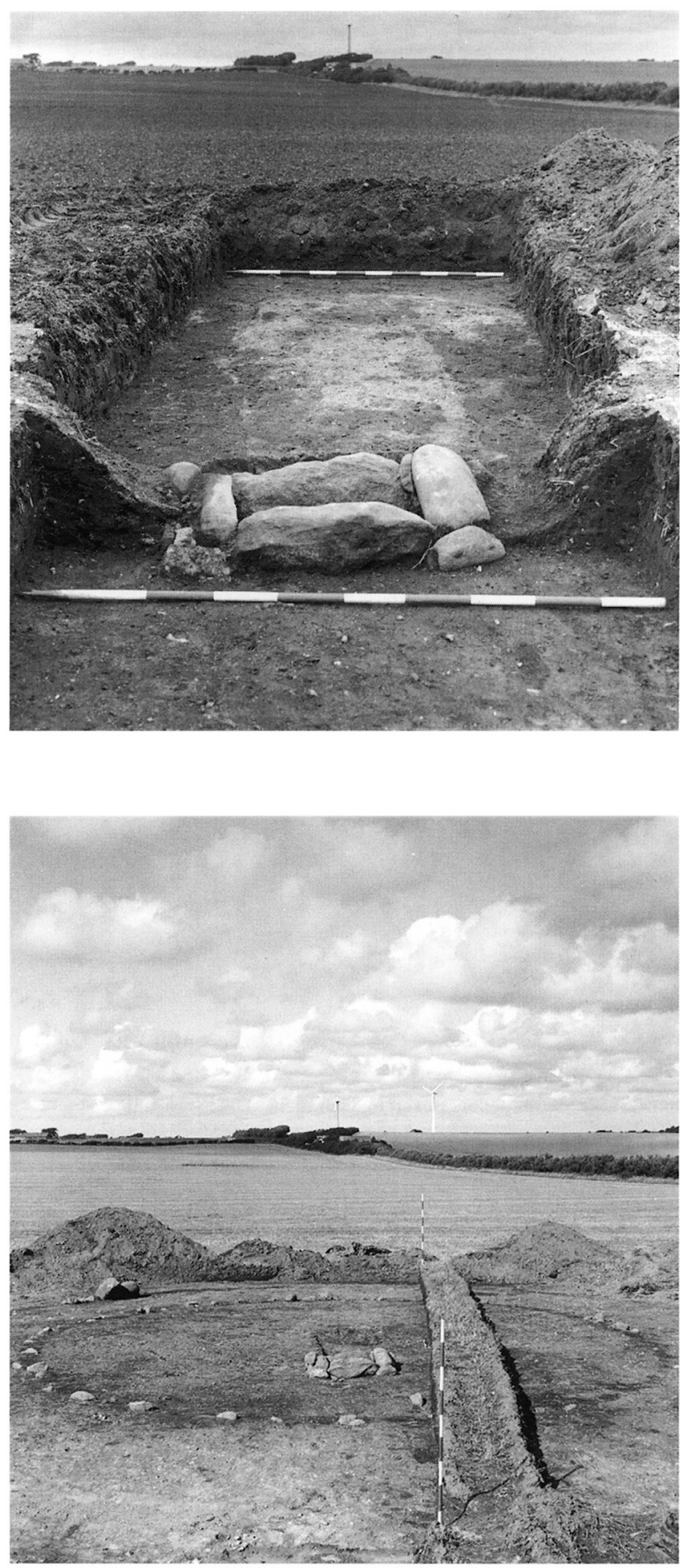

Fig. 3. Stenkisten fra Damsgård set fra syd. I baggrunden fyldskiftet til ligbrændingsgruben.

The stone cist from Damsgarrd seen from the south. In the background the funeral pyre pit can be seen.
Fig. 4. Højen set fra syd med stenkiste og ligbrændingsgrube omgivet af de bevarede dele af randstenskæderne. Tydeligst står højens rldste fase.

The burial mound seen from the south with the stone cist and the pyre pit surrounded by the remaining members of the kerb stones. The mound's oldest phase is seen most clearly. 


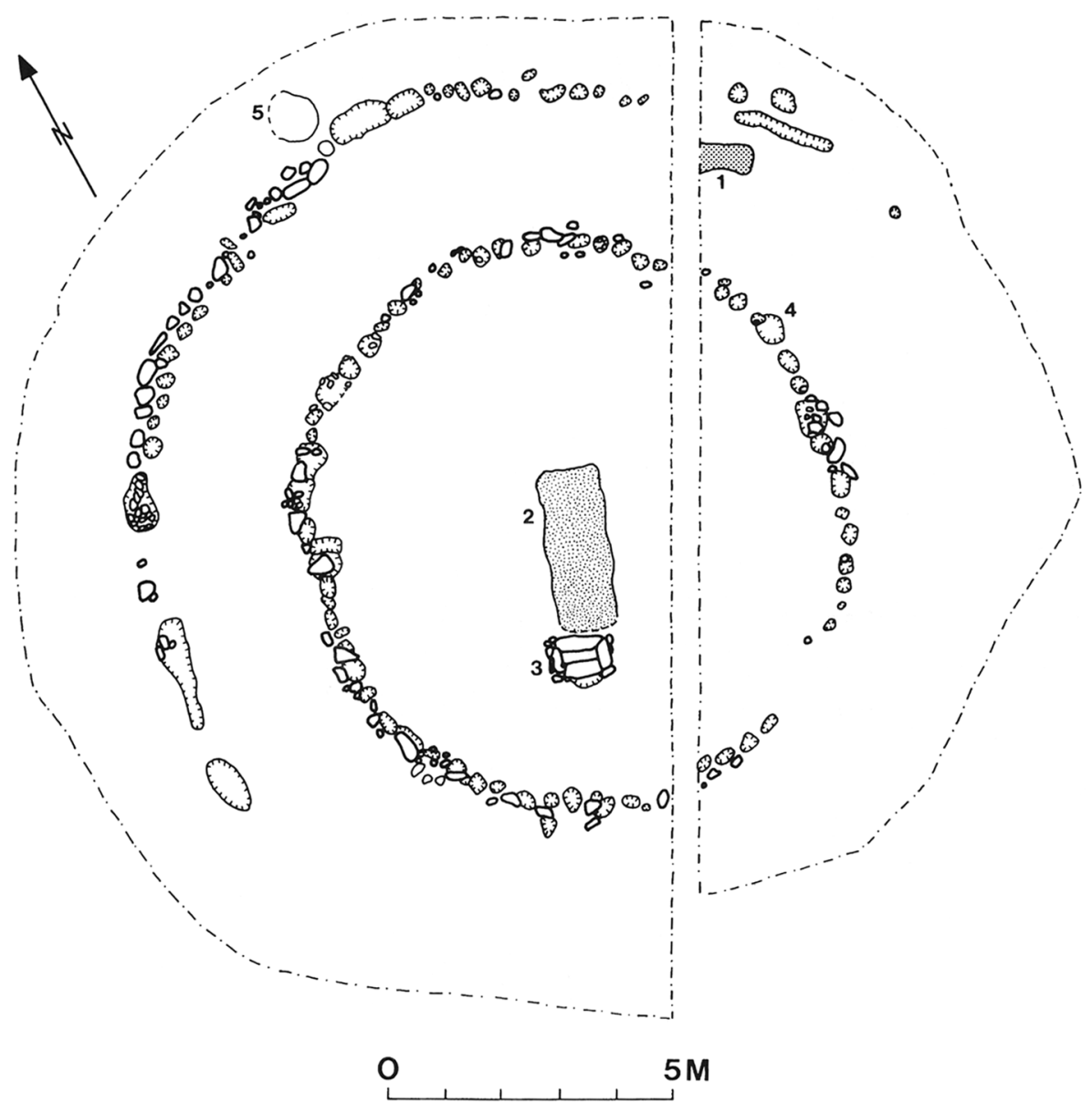

Fig. 5. Plan over højen. 1: Sekundær jernaldergrav, 2: Ligbrændingsgrube, 3: Stenkiste, 4: Stenspor, 5: Grube. Datering uvis.

Plan of the mound. 1: Secondary Iron Age grave, 2: Pyre pit, 3: Stone cist, 4: Depressions from where stones have been removed, 5: Pit of unknown date.

gravudstyr. Den er blevet nedgravet i den nordre kant af højen ca. $1 \mathrm{~m}$ indenfor højfoden til fase $2 \mathrm{og}$ tilhører formentlig yngre romertid eller germansk jernalder.

Tydelige stenspor og enkelte tilbageblevne støttesten til fjernede randsten viste, at højen i sin første fase har haft en svagt langoval form, $10 \mathrm{~m}$ i diameter i $\mathrm{N}-\mathrm{S}$ og 9,5 $\mathrm{m}$ i $\varnothing-\mathrm{V}$, med stenkisten anbragt kun 2,5 $\mathrm{m}$ indenfor den sydlige højfod. Mere centralt placeret var derimod ligbrændingsgruben, hvis nordlige halvdel har ligget lige under højcentrum.

Af et N-S snit igennem højen anlagt 1,5 m øst for højcentrum fremgår det, hvor lidt der var tilbage af selve højopbygningen, nemlig kun et op til $10 \mathrm{~cm}$ tykt lag urørt højfyld i den centrale del af højen (fig. 6, lag 2). Det lå ovenpå et 


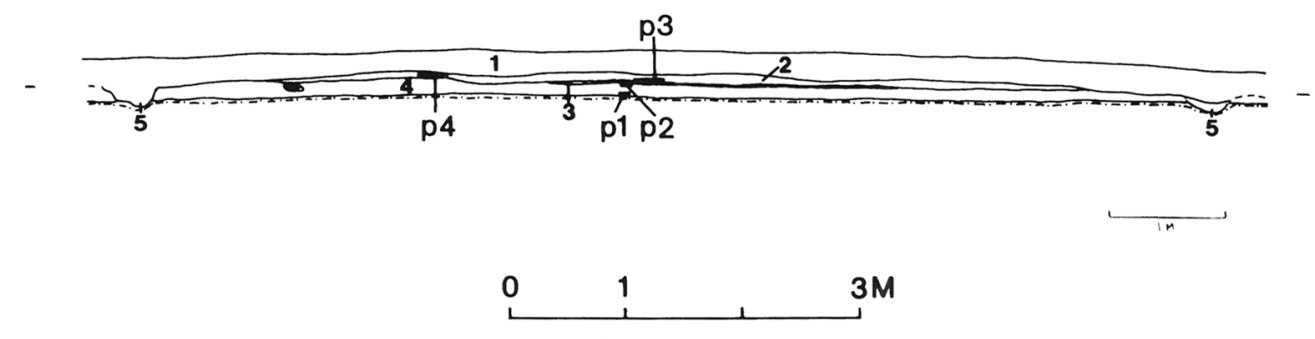

Fig. 6. Profilsektion af den centrale del af højen. 1: Moderne pløjelag. 2: Mørkbrunt leret sand med enkelte linser af hvidgult til brungult leret sand. Højfyld fra ældste højfase med enkelte erkendbare tørv. $3: 0,5-2,0 \mathrm{~cm}$ tyk stribe af hvidgult til brungult leret sand. Undergrundsmateriale fra gravning af ligbrændingsgrube. 4: Mørkbrunt til gråbrunt leret sand, 9-11 cm tykt. Muldlag ved anlæggelsen af højen. 5: Stenspor fra fjernet randsten. p 1: Pollenprøve (jvnf. fig. 33b analyse nr. 1). p 2: Pollenprøve (jvnf. fig. 33b analyse nr. 2). p 3 : Pollenprøve (jvnf. fig. 33b analyse nr. 3). p 4: Pollenprøve (jvnf. fig. 33b analyse nr. 4).

Section through the central part of the mound. 1: modern plough-soil. 2: Dark brown clayey-sand with occasional lenses of whitish-yellow to brownish-yellow clayey sand. The core of oldest phase of the burial mound with occasional recognisable turves. $3: 0.5-2.0 \mathrm{~cm}$ thick stripe of whitish-yellow to brownish-yellow clayey sand. Sub-soil thrown up during digging of the pyre pit. 4: Dark brown to greyish-brown clayey sand, 9-11 cm thick. Old land surface at the time of construction of the mound. 5: Grey-brown clayey sand. Traces from the missing kerbstones. p 1: Pollen sample (see fig. 33 analysis no. 1). p 2: Pollen sample (see appendix 4 analysis no. 2).p 3: Pollen sample (see fig. 33 analysis no. 3). p 4: Pollen sample (see fig. 33 analysis no. 4)

relativt tyndt gammelt muldlag på fra 9 til $11 \mathrm{~cm}$ 's tykkelse (fig. 6, lag 4). Adskillelsen mellem højfylden og det gamle muldlag var skarpt tegnet, idet der ved gravningen af ligbrændingsgruben og opførelsen af stenkisten var kastet et 0,5-2 cm tykt lag af undergrundens gulbrune lerede sand op ovenpå det daværende muldlag (fig. 6, lag 3). I profilet kunne dette opsmidslag følges over godt $3 \mathrm{~m}$.

\section{Kisten}

Stenkisten, der gav anledning til undersøgelsen, var opbygget af fire sten med de to største anbragt parallelt med hinanden i kistens længderetning ØSØVNV. Afstanden mellem de to sten var øverst i kisterummet ca. $40 \mathrm{~cm}$, og da den ene af stenene skrånede indad mod gravbunden, var denne kun ca. $20 \mathrm{~cm}$ bred. Dybden af kisterummet var $30 \mathrm{~cm}$, længden $70 \mathrm{~cm}$ (jvnf. fig. $7 \mathrm{a}$ ).

Ved åbningen af kisten sås øverst under den indskredne løse jord, ca. $20 \mathrm{~cm}$ under toppunktet af den nordlige sten i langsiden, et to centimeter tykt lag af gullig aske og mindre trækulsstykker. Dette lag dækkede de brændte ben i kisten, der lå oven på en bundbelægning af småsten.

\section{Oldsagerne $i$ kisten}

Mellem de brændte ben fandtes tæt op ad kistens nordlige langside en bøjlenål af bronze (fig. 8a), der var nedlagt i graven i to stykker med ca. $10 \mathrm{~cm}$ 's afstand. Desuden lå der mellem de brændte ben et mindre brudstykke af en lille énægget bronzekniv med rammegreb (fig. 8b). Ved en nærmere gennemgang af de brændte knogler fra kisten efter afslutningen af udgravningen fremkom endvidere et $5,5 \mathrm{~cm}$ langt brudstykke af en uornamenteret bennål (fig. $8 \mathrm{c}$ ). 
Fig. 7a: Plan af stenkisten og ligbrændingsgruben. 1: Brdst. af kniv (fig. 8b). 2: To samhørende dele af bøjlenål (fig. 8a). 3: Armring (fig. 8d). 4: Spiralring (fig. 8e).

Plan of the stone cist and the pyre pit. 1: Fragment of knife (fig. 8b). 2: Two parts of the same fibula (fig. 8a). 3: Armring (fig. 8d). 4: Spiral ring (fig. $8 \mathrm{e}$ ).

Fig. 7b. Snit A-B og C-D af ligbrændingsgrube. 1: Gråbrunt humøst leret sand. Græstørv. 2: Gulbrunt leret sand med pletter af gråbrunt humøst leret sand. Opgravet undergrundsmateriale. 3: Rødgult til lysgult, fedtet lag, stærkt flammet, med hvidgrå partier, trækulsstykker og stumper af brændte knogler. Aske/brandlag. 4: Gråt til gråsort fedtet lag. Aske-/brandlag. 5: Homogent sort til sortbrunt lag af blød konsistens. Mere porøst og flaget end lag 3 og 4, men uden træstruktur og med tendens til indre lagdeling. Tørv. 6: Rødgråt leret sand. Ildpåvirket undergrund. 7: Nedgravning omkring kiste. 8: Mørkbrunt- til gråbrunt leret sand. Gl. muldlag. $U=$ Gulbrunt leret sand med mange småsten. Undergrund. $\mathrm{a}=$ armring fig. $8 \mathrm{~d}$.

Sections A-B and C-D through the pyre pit. 1: Greyish-brown organic clayey sand. Turves. 2: Yellowish-brown clayey sand with patches of greyish-brown organic clayey sand. Upturned sub-soil. 3: Strongly flamed reddish-yellow to light yellow greasy layer, with whitish-grey patches, charcoal fragments and pieces of burnt bone. Ash/ burnt layer. 4: Grey to greyish-black greasy layer. Ash/burnt layer. 5: Homogenous black to blackishbrown layer of a soft consistency. More porous and flaky than layers 3 and 4, but without obvious woody structure and with a tendency towards internal stratification. Peat. 6: Reddish-grey clayey sand. Burnt sub-soil. 7: Dug-out area around the cist. 8: Dark brown to greyish-brown clayey sand. Buried soil. $\mathrm{U}=$ yellowish-brown clayey sand with abundant small stones. Subsoil. a $=$ arm-ring fig. $8 \mathrm{~d}$.

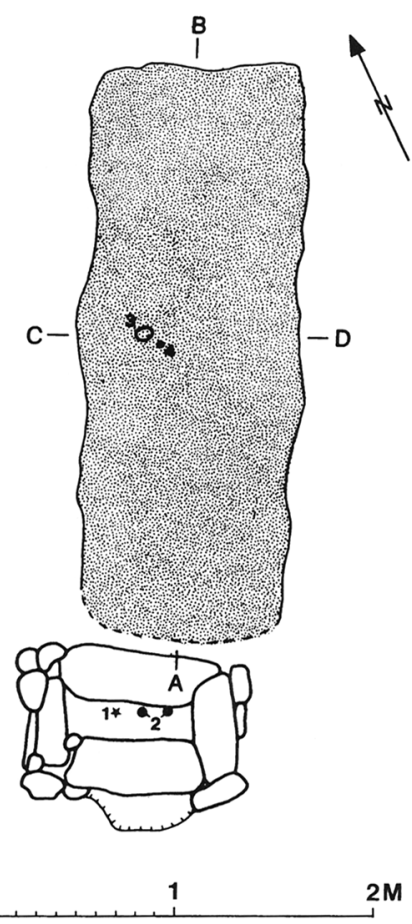

$7 a$

A
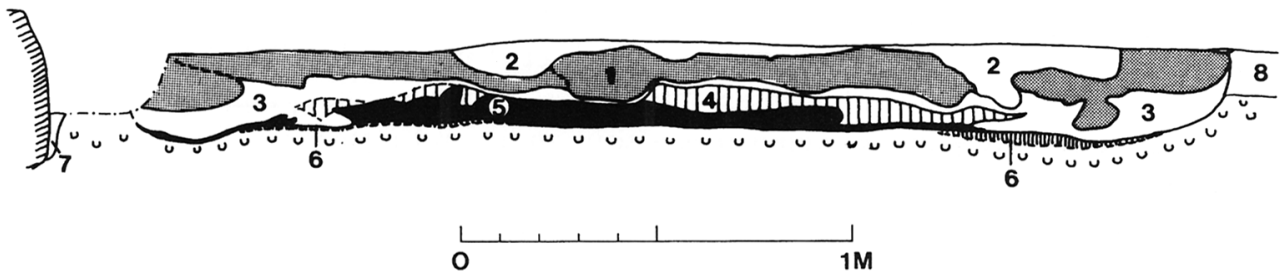

C

D

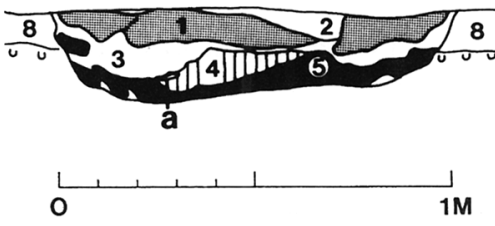

$7 b$ 
Bøjlenålen er $8 \mathrm{~cm}$ lang, har fladhamret spiral og afrundet bøjletværsnit (fig. 8a). Desværre er det ikke muligt at sige noget om udformningen af hovedet på bøjlenålen, men udfra dens spinkle udførelse er der givetvis tale om en bøjlenål fra ældre bronzealder per. III. Denne datering stemmer ydermere med tidsfæstelsen af bronzekniven med rammegreb (fig. 8b), som tilhører en relativt almindelig gruppe knive, der hører hjemme under toiletudstyret i per. III (Broholm 1944, 156). Brudstykket af den uornamenterede bennål (fig. 8c) kan i denne sammenhæng ikke bidrage til dateringen af graven. Bennåle er sjældne i grave fra per. III, i modsætning til i per. IV, men de kendes dog (5).

\section{Ligbrcendingsgruben}

Nord for stenkisten fandtes et omtrent NØ-SV orienteret, rektangulært fyldskifte, 2,8x1,2 m med en dybde på $0,28 \mathrm{~m}$. (fig. 7a-b). I snit stod det som en lav, fladbundet grube, der var gravet gennem den gamle muldhorisont under højen og ned i undergrunden.

Overst i gruben sås tydeligt aftegnet 3 langsgående rækker af græstørv, der målte 30x25-30 cm og var 10-12 cm tykke (fig. 7b, lag 1, jvnf. også fig. 9). Tørvene var delvis dækkede af genfyldt, opgravet undergrundsmateriale (fig. 7b, lag 2). Efter optømning af hver enkelt tørv sås under disse et sammenhængende aske- og trækulslag, i hvis overflade tørvene havde lavet aftryk som følge af, at de var lagt oven på brandlaget, mens dette endnu var blødt, og var sunket delvis ned i det.

Brandlaget bestod øverst af rødgul til lysgul, fedtet aske flammet med hvidgrå partier og med spredte trækulsstykker på op til $9 \mathrm{~cm}$ 's længde og $7 \mathrm{~cm}$ 's tykkelse (fig. 7b, lag 3). Laget var af samme karakter som det gullige askelag øverst i stenkisten. Endvidere fandtes i dette lag spredte, overvejende små, stykker brændt knogle i størstedelen af gruben. Øverst i det underliggende grå til gråsorte, fedtede askelag (fig. $7 b$, lag 4) lå i grubens nordende et større stykke af hjerneskallen. På fotografiet fig. 10 ses kraniebrudstykket under landmålerstokken i billedets højre del.

På overgangen mellem de to askelag fandtes, omtrent midt i gruben, en armring af bronze (fig 8d). Igennem denne stak et større stykke dårligt forbrændt lemmeknogle. Ca. $10 \mathrm{~cm}$ fra ringen fandtes resterne af en lille spiralring af bronze (fig. 8e). Dette kan vanskeligt tolkes som andet end resterne af ligets underarm, der er blevet brændt med ringen siddende på og derpå er sunket så langt ned $i$ asken, at hverken knoglen, armringen eller spiralringen (fingerringen?) er kommet med ved den efterfølgende indsamling af de brændte knogler m.m.

Under det rødgule og det gråsorte askelag fremkom i grubens midterdel, over en strækning på ca. 1,4 m, et kompakt lag af sort, forkullet materiale uden nogen træstruktur, $2-10 \mathrm{~cm}$ tykt (fig. $7 \mathrm{~b}$, lag 5 samt fig. 10-12). Laget var temmelig blødt og gik ved skrabning op i talrige små, filtagtige flager. Et enkelt sted sås en struktur, der lignede forkullede strå. Enkelte steder nederst i laget var farven endvidere ikke sort, men brun, som om der ikke var foregået en fuldstændig forkulning.

Det sorte lag gik op langs grubens sider og sås stedvis som firkantede blokke på 5-6 cm's tykkelse, der ved udgravningen blev tolket som mose- eller hedetørv. På profiltegningen fig. $7 b$, snit C-D ses i venstre side en sådan firkant et 

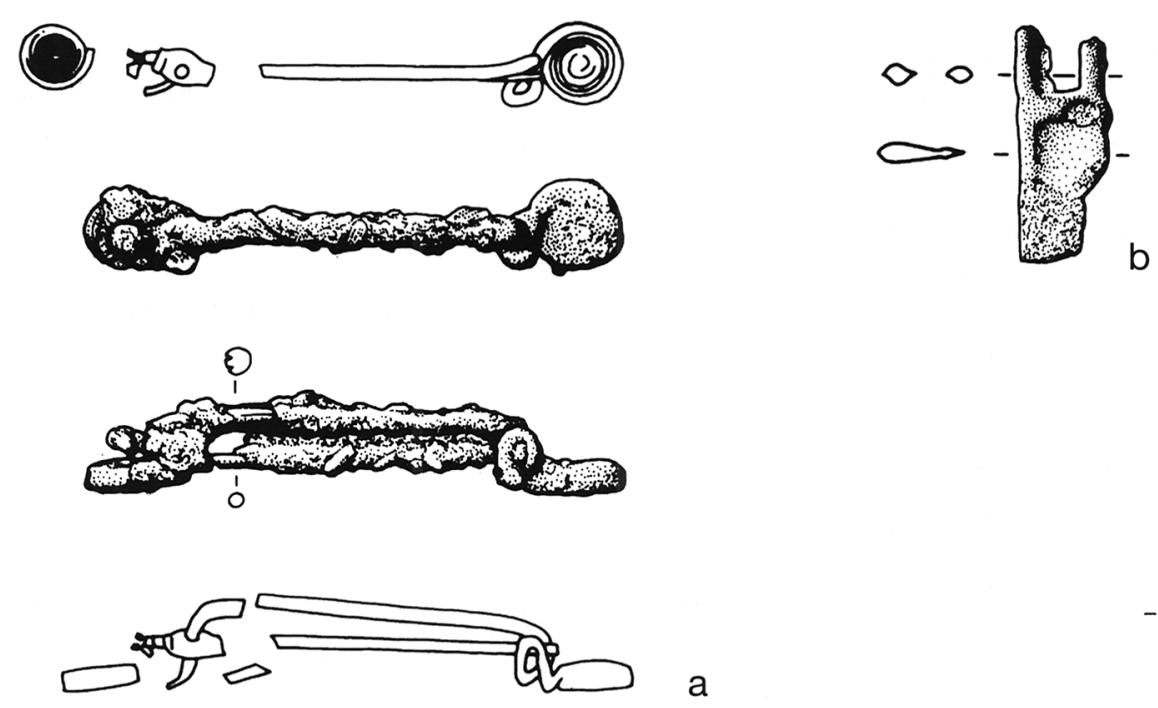

b

a
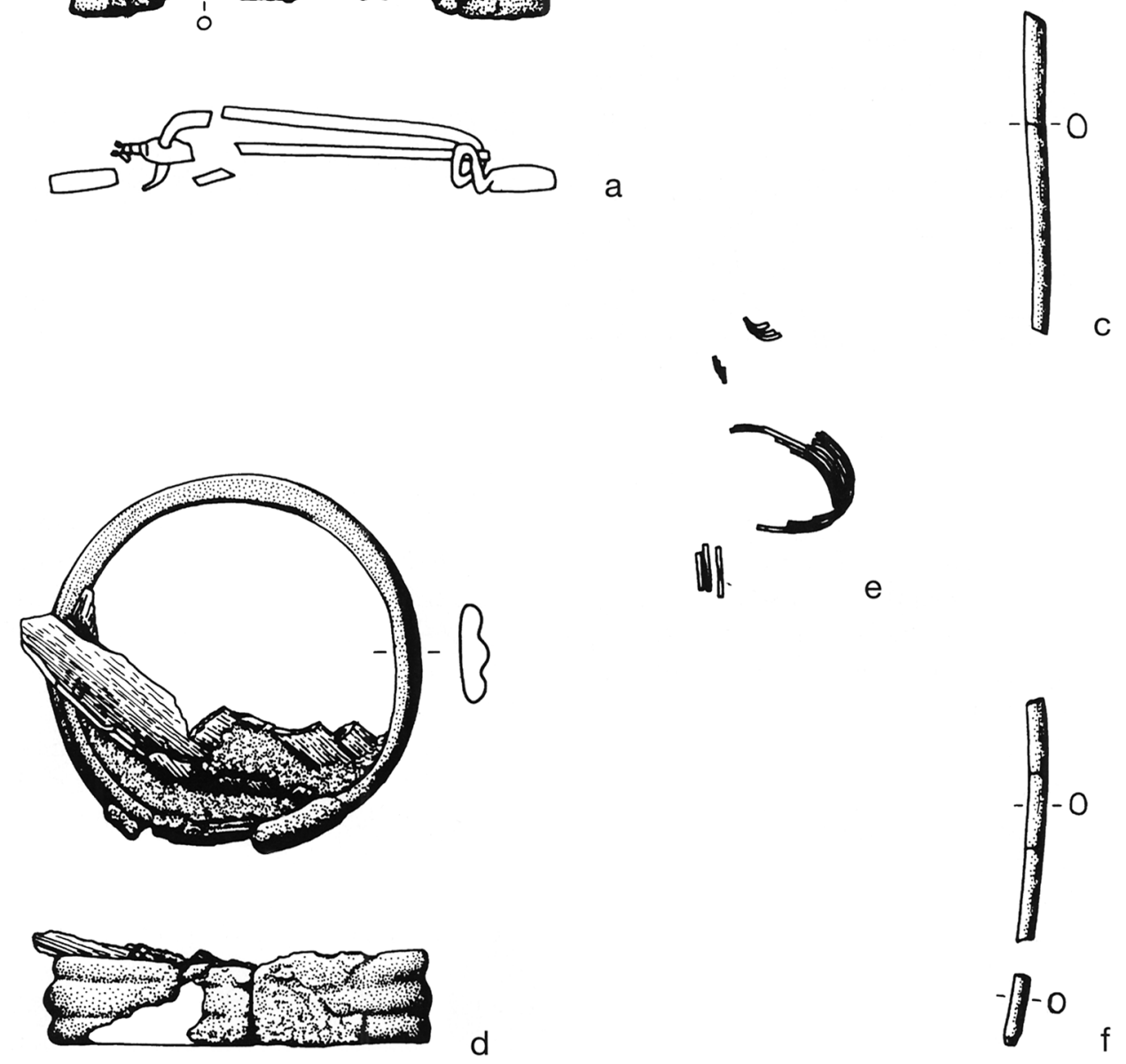

Fig. 8. Oldsager fra stenkiste $(a-c)$ og ligbrændingsgrube (d-f). 2:3. a: Bøjlenål af bronze m. udtegning fra røntgenfoto. b: Brudstykke af énægget bronzekniv med rammegreb. c: Brudstykke af bennål. d: Bronzearmring med isiddende del af brændt lemmeknogle. e: Brudstykke af spiralring af bronze (efter røntgenfoto). f: Brudstykker af bennål.Tegning: Eva Koch. 2:3.

Finds from the stone cist $(\mathrm{a}-\mathrm{c})$ and the pyre pit (d-f). 2:3. a: Bronze fibula with outline from radiograph. b: Fragment of single-edged bronze knife with open haft. c: Fragment of bone pin. d: Bronze armring with fragment of burnt limb bone in situ. e: Fragment of bronze spiral ring (after radiograph). f: Fragment of bone pin. $2: 3$. 


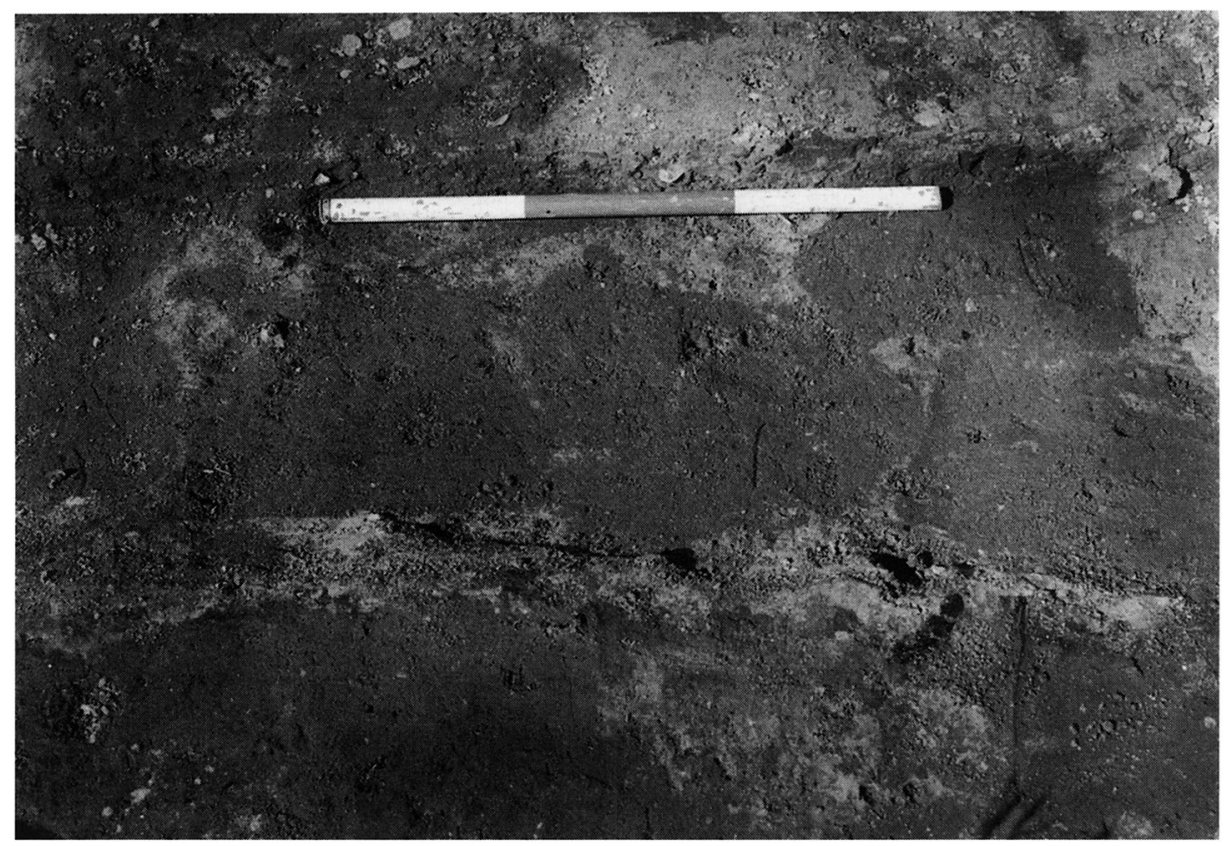

Fig. 9. Græstørv øverst i ligbrændingsgrube.

Turves uppermost in the pyre pit.

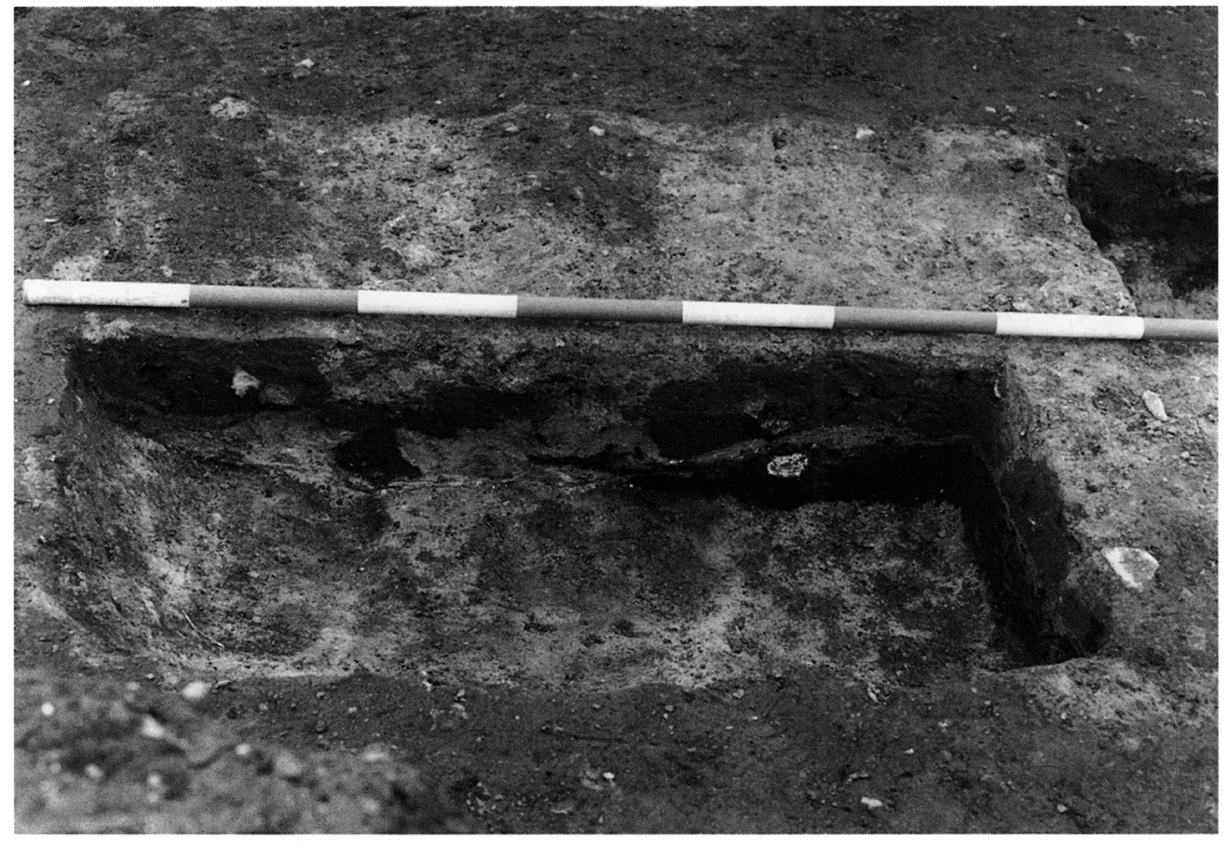

Fig. 10. Længdesnit i nordlige del af ligbrændingsgrube (jvnf. fig. 7b).

Longitudinal section through the northern part of the pyre pit (cf. fig. $7 \mathrm{~b}$ ). 


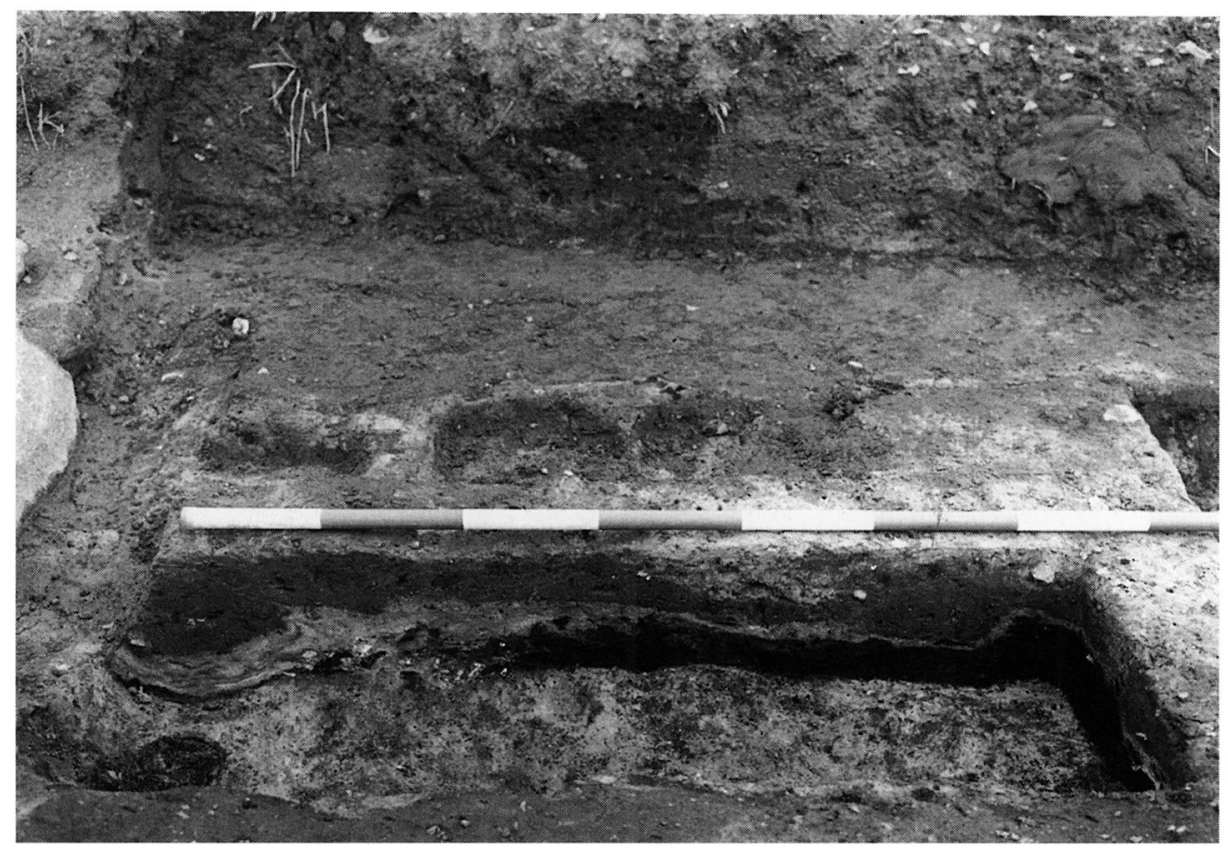

Fig. 11. Længdesnit i sydlige del af ligbrændingsgrube (jvnf. fig. 7b).

Longitudinal section through the southern part of the pyre pit (cf. fig. $7 \mathrm{~b}$ ).

stykke oppe ad grubens side, samt tre lignende stående på højkant på grubens bund. Mellem disse ses tynde faner af gråhvid og rødgul aske. I snittets modsatte side er forholdene de samme (jvnf. fig. 12-13).

Hvor ligbrændingsgruben skæres vinkelret af snit C-D (fig. 7b), ses det sorte materiale i den midterste del som et kompakt lag, der sammen med det gråsorte askelag danner en slags "forhøjning“, over og omkring hvilken der ses rødgul og gråhvid aske, jvnf. også fig. 12. Nordligst og sydligst i gruben var det sorte, kompakte lag erstattet af rødgul og gråhvid aske. I de samme områder fandtes endvidere ildpåvirkning af undergrunden, hvilket manglede i grubens centrale del. Det sorte kompakte lag tolkes derfor som en kun delvis brændt rest af den nederste del af ligbålet, der i grubens midterdel har været beskyttet mod de høje brændingstemperaturer af den dødes krop, hvorimod en sådan beskyttelse ikke har været tilstede i enderne, hvorfor det også er her, ildpåvirkningen af undergrunden kan iagttages. Er denne forklaring korrekt, viser den også, at forbrændingen i ligbålet hovedsagelig er foregået ovenfra (Sml. Wahl \& Wahl 1983, 514).

\section{Oldsagerne i ligbrandingsgruben}

I ligbrændingsgruben fandtes som nævnt også enkelte oldsager, der er blevet overset ved indsamlingen af ligrester forud for selve gravlæggelsen. Det drejer sig om en bronzearmring, en spiralring af bronze samt brudstykker af en eller to bennåle, der blev erkendt under gennemgangen af de brændte ben. 


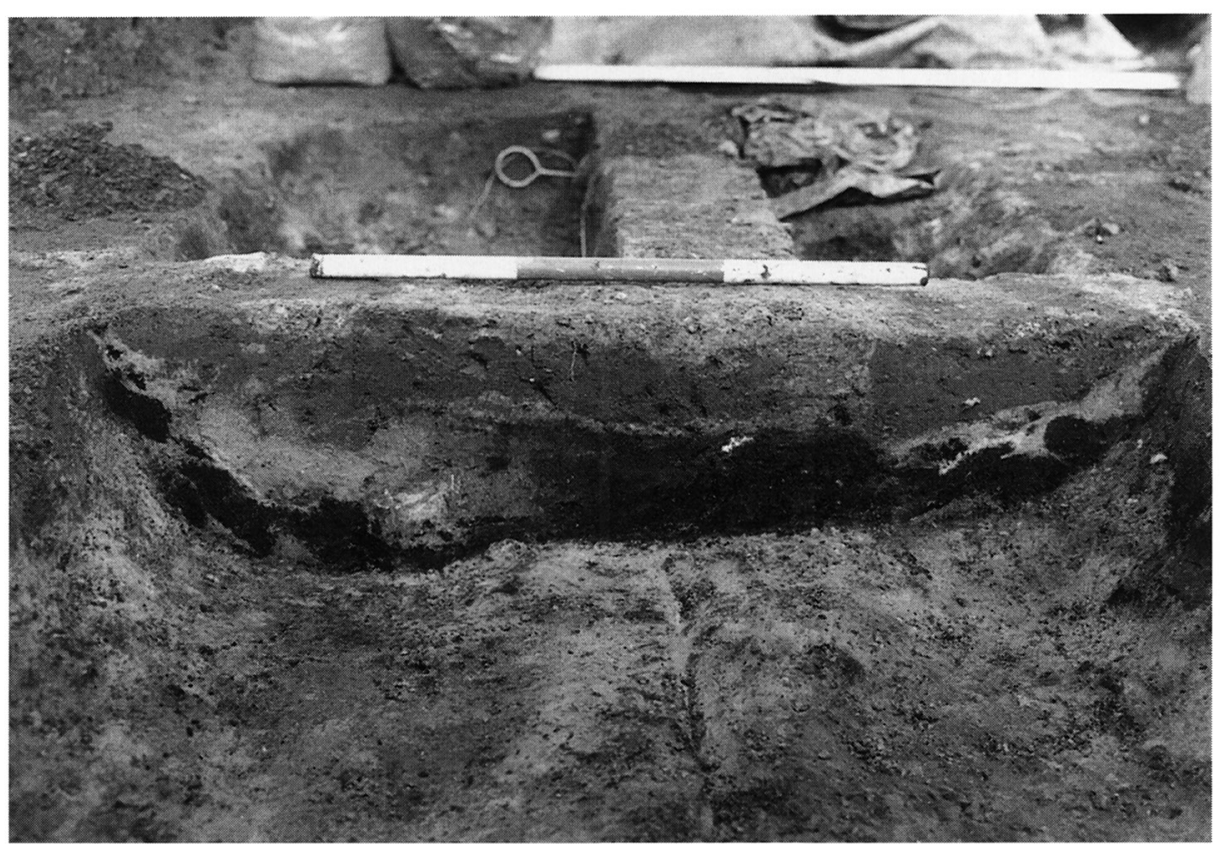

Fig. 12. Tværsnit af ligbrændingsgrube (jvnf. fig. 7b).

Cross-section through the pyre pit (cf. fig. $7 \mathrm{~b})$.

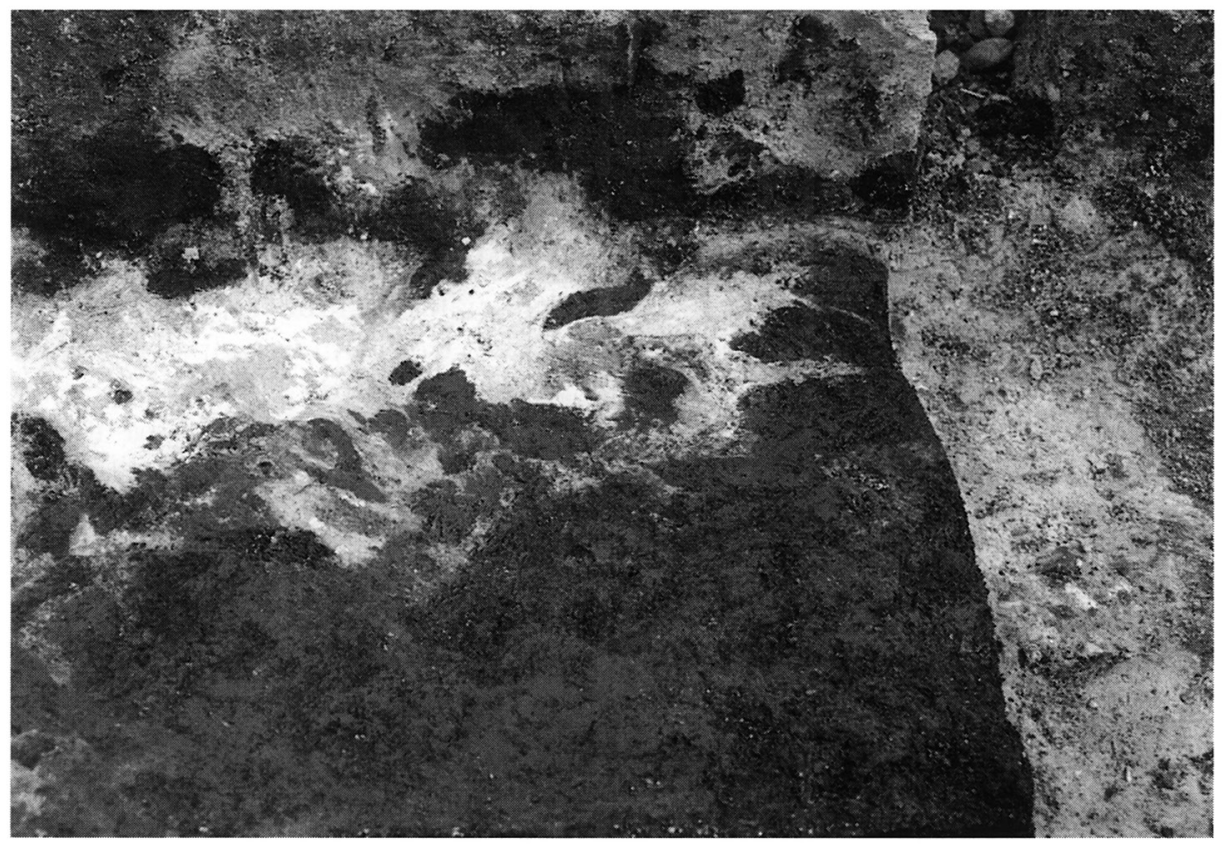

Fig. 13. Detail af bundlag i ligbrændingsgrube med klumper af kun delvis forbrændte tørv.

Close-up of the basal layer in the pyre pit showing clumps of partially-burnt peat. 
Armringen fig. $8 \mathrm{~d}$ er båndformet og åben i den ene side. Den måler $6,5 \mathrm{~cm}$ i diameter og er 1,7 cm høj. Ydersiden er udsmykket med 3 glatte, omløbende vulste. Til trods for, at den blev fundet i ligbålet med en isiddende, forbrændt knogle, ses ingen sikre spor af varmepåvirkning, hvilket betyder, at temperaturen må have ligget under bronzens smeltepunkt, der er omkring 1000 grader Celsius (Wahl 1982, 21). Dette bekræftes af undersøgelsen af de brændte ben (se nedenfor). Armringen har stor lighed med afbildningerne fig. 297-298 i Danske Oldsager bd. III, og den må dateres til ældre bronzealder per. III.

Spiralringen af bronze fig. 8e er så medtaget, at den kun foreligger indstøbt i et præparat. Tegningen er derfor udført efter røntgenbilledet, der viser en spinkel, tæt oprullet bronzetråd med mindst otte vindinger. Diameteren kan ikke afgøres med sikkerhed. Ringen lader sig vanskeligt datere nøjagtigt, men strider ikke mod armringens datering af fundet til per. III. Ud fra dens placering i gruben er det nærliggende at tolke den som en fingerring.

Knoglenålen eller -nålene fig. 8f fandtes som fire brændte fragmenter, hvoraf de tre er samhørende. Det kan ikke afgøres, om det fjerde stykke stammer fra den samme nål. Stykkerne er desuden søgt sammensat med brudstykket fra stenkisten, men uden held. Nålen eller nålene, der fandtes sammen med kraniefragmenter i grubens nordlige del, kan evt. have siddet i et klædningsstykke, der har ligget under den dødes hoved, eller i selve håropsætningen.

\section{Samlet vurdering af oldsagerne fra kisten og gruben}

Oldsagerne fra stenkisten og ligbrændingsgruben giver samstemmende en datering af fundet til ældre bronzealder per. III. De udgør tilsammen et ganske velassorteret, men ikke overdådigt, kvindeudstyr omfattende: Bøjlenål, armring, kniv og spiralring, antagelig fingerring, alt af bronze, samt en eller flere nåle af ben. Der er intet i udstyret, som tyder på tilstedeværelsen af flere personer. Fundet af armringen og bronzespiralen i ligbålet maner til forsigtighed ved tolkning af gravudstyret i brændtbensbegravelser, hvor det åbenbart ikke blot er smågenstande, der kan være overset ved gravlægningen (Henriksen 1993, 107f; Mckinley 1994).

\section{Analyse af de brandte ben}

De brændte ben fra såvel stenkisten som ligbrændingsgruben blev analyseret af Pia Bennike, Antropologisk Laboratorium, se appendix 1 s. $188 \mathrm{f}$ nedenfor.

Resumé af undersøgelsesresultatet: Blandt knoglerne fandtes klart samhørende stykker af samme knogle henholdsvis i kisten og i gruben, bl.a. passede kraniedele fra gruben sammen med fragmenter fra stenkisten (fig. 14). Der var ikke tegn på tilstedeværelsen af mere end én person. Det kan således anses for bevist, at knoglerne fra kisten og fra ligbrændingsgruben tilhører én og samme person.

Den døde blev bestemt som en voksen, yngre person på 25-35 år. Kønsbestemmelsen var mere usikker, og konklusionen blev, at der kan være tale om en mand, men at denne bestemmelse var forbundet med usikkerhed. I lyset af gravudstyret må det imidlertid anses for sikkert, at den afdøde var en kvinde. I ligbrændingsgruben fandtes enkelte knogler, som muligvis kan stamme fra et dyr; hvilket der i så fald er tale om, kan ikke afgøres. 


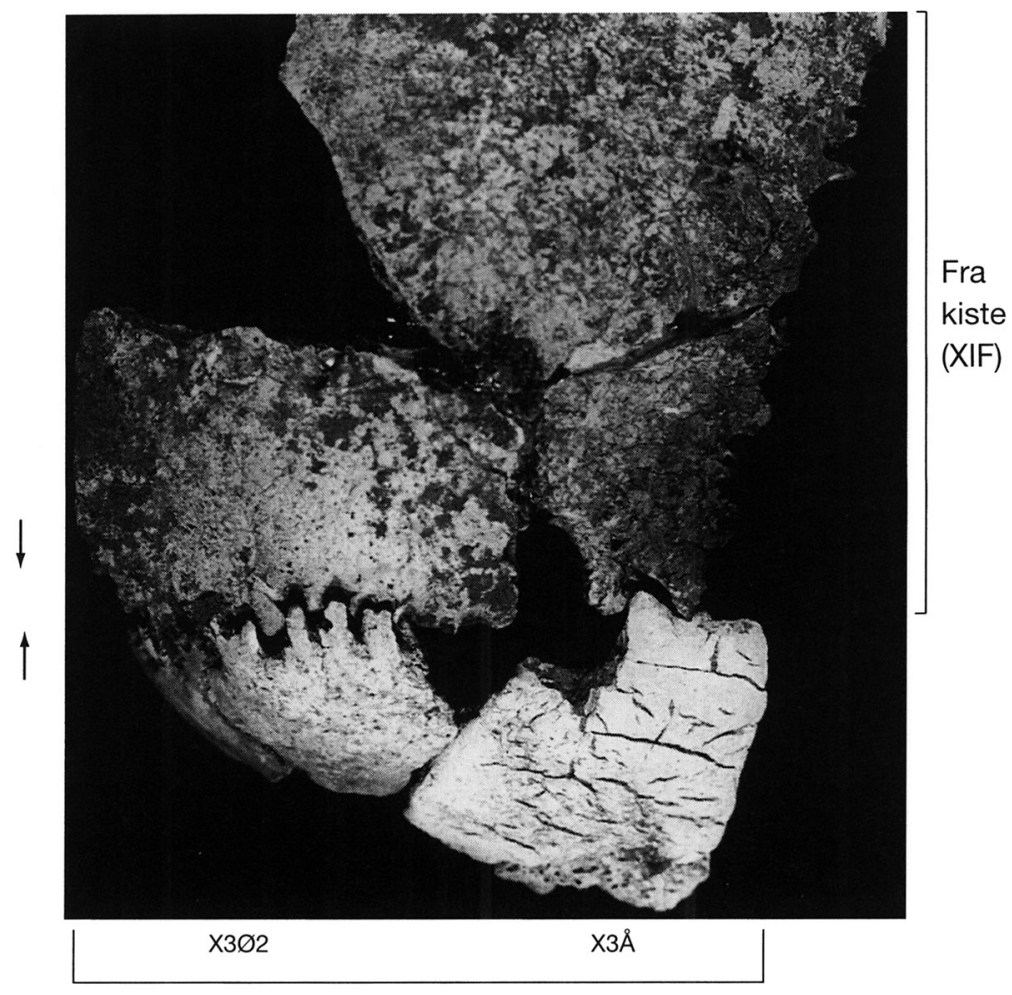

Fra ligbrændingsgrube

Fig. 14. Samhørende stykker af kraniekalot fra kiste og ligbrændingsgrube. Foto: Grazyna Hahn.

Two fragments of the same cranium found in the cist and the pyre pit respectively.

Placeringen af de forskellige typer knoglefragmenter i gruben fremgår af fig. 15. Der er tydeligvis sket en vis forstyrrelse af de tiloversblevne knogler ved indsamlingen forud for gravlæggelsen, men fundet af en koncentration af fodknogler $i$ sydenden af gruben, en del kraniefragmenter ca. 1,6 m nord herfor samt armringen med den isiddende lemmeknogle ca. midtvejs viser dog, at den døde har været anbragt udstrakt eller let sammenbøjet med fødderne i syd og hovedet i nord, omtrent hvor højens centrum ligger.

Spørgsmålet om, hvorvidt liget har ligget på ryggen eller på siden, er vanskeligere at afgøre. Med henblik herpå blev det ved knoglegennemgangen registreret, om knoglen var sortfarvet - brændt ved relativt lav temperatur - eller hvid og brændt ved en højere temperatur. Dette gav dog ikke noget entydigt billede.

En prøve af en sortbrændt del af en lårbensknogle blev undersøgt for tilstedeværelsen af organisk materiale (collagen). Undersøgelsen viste, at der var $8,5 \%$ organisk materiale tilstede, hvilket betyder, at brændingstemperaturen for denne knogle har været mellem 400 og 600 grader Celsius. Mellem knoglerne blev fundet et ubestemmeligt, slaggeagtigt materiale (jvnf. nedenfor s. 191). 
Prøver af trækullet fra ligbrændingsgruben blev undersøgt på NNU af Kjeld Christensen, se appendix 2 s. 190 nedenfor (jvnf. Christensen \& Robinson 1995).

Resumé af undersøgelsesresultatet: Undersøgelsen viste, at størstedelen af stykkerne stammede fra Ask med et mindre indslag af Bævreasp. Andre træarter blev ikke påvist. Asketrækullet stammede fra grenved, de fleste stykker antagelig fra grene med en diameter på 5-10 cm, hvilket stemmer med iagttagelser gjort under udgravningen, hvor dele af store brændestykker helt manglede. I trækulprøven fandtes endvidere også klumper af et opblæret, slaggeagtigt materiale (jvnf. s. 191). Slaggerne fandtes dels alene, dels fastsiddende på trækullet.

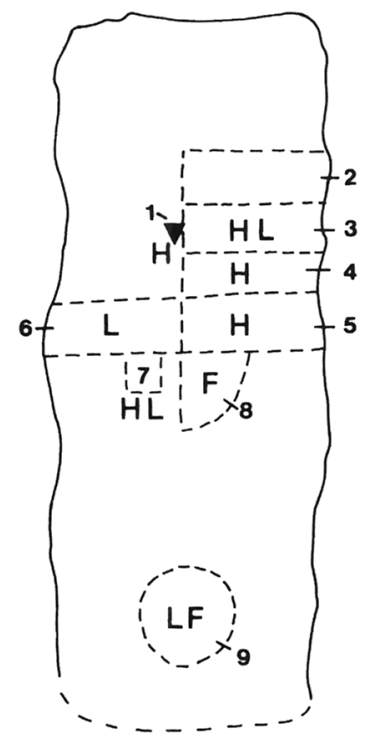

0

Fig. 15: Områder i ligbrændingsgruben med bestembare knoglefragmenter (analyseret af Pia Bennike, jvnf. appendix 1). 1: 6 sammenhørende kraniefragmenter. 2: Fragment fra en hvirvel. 3: Få kraniefragmenter, fragmenter fra en større lemmeknogle samt hvidlige rødder fra to enrodede tænder. Blandt knoglerne også 1 brdst. af bennål. 4: Få fragmenter fra kraniet. Blandt knoglerne også 3 brdst. af bennål. 5: Enkelte kraniefragmenter. 6: Småfragmenter bl.a. fra mindre lemmeknogler. 7: Talrige småfragmenter, et enkelt fra kranium, de øvrige fra mindre lemmeknogler f.eks. fra underarmene. 8: Tåknogle. 9: Flere fragmenter fra mellemfodsknogler samt enkelte tåknogler. Desuden fragmenter fra lemmeknogler feks. fra skinneben og lægben. Signaturer: H: Fragmenter af kranie eller tænder. L: Lemmeknogler. F: Mellemfods- eller tåknogler.

Areas of the pyre pit showing the locations of the identifiable bone fragments (analysed by Pia Bennike cf. appendix 1). 1: 6 fragments of the skull. 2: Fragment of a vertebra. 3: A few skull fragments, fragments of a large limb bone plus whitish roots from two single-rooted teeth. Among the bones there is also a fragment of bone pin. 4: A few skull fragments. Among the fragments there are also three fragments of bone pin. 5: Occasional skull fragments. 6: Small fragments, including some from small limb bones. 7: Numerous small fragments, including a skull fragment, the remainder from small limb bones, for example from the lower arm. 8: Phalanx (toe bone). 9: Several fragments of metatarsal (foot bones) plus occasional phalanges (toe bones). In addition there are fragments of limb bones, for example from the lower leg (shin and calf bones). Key: $\mathrm{H}$ : fragments of skull or teeth. L: limb bones. F: metatarsals or phalanges (foot or toe bones). 
Makrofossilanalyse af brandlaget $i$ gruben

Under udgravningen var det påfaldende, at store dele af asken havde en stærkt rødgul til lysgul farve, der næppe kunne stamme fra et vedbål alene. Det samme gjaldt det sorte, finkornede lag uden træstruktur, der fandtes nederst i gruben og langs siderne. Det så derfor ud til, at der ved ligbrændingen ud over træ var anvendt et andet materiale som brændsel. Allerede under udgravningen blev det sorte lag forsøgsvis tolket som dårligt forbrændte tørv og den rødgule aske som tørveaske. Denne teori blev efterprøvet gennem makrofossilanalyse af prøver af brandlaget.

Makrofossilanalyser af brandlaget i ligbrændingsgruben blev udført af David Robinson, NNU se appendix 3 s. $191 \mathrm{f}$ (jvnf. Christensen \& Robinson 1995).

Resumé af underøøgelsesresultatet: Makrofossilanalyse af det sorte brandlag viste, at det bestod af klumper af findelt plantemateriale, fortrinsvis græsser eller halvgræsser. En del af materialet var brunfarvet og vidnede om svag varmepåvirkning. I en enkelt prøve fandtes mange frø og andre makrofossiler, i de øvrige kun fă. Så godt som alle makrofossiler stammer fra arter, der hører hjemme i jyske hedemoser. Endvidere indeholdt prøverne også det ovenfor omtalte slaggeagtige materiale, der foreløbig tolkes som forbrændte rester af kød og hud.

Det var nærliggende ud fra analysen at konkludere, at laget som antaget bestod af tørv, men en anden mulighed: At der var tale om brændt gødning fra husdyr, som havde græsset $\mathrm{i}$ en hedemose, måtte også tages i betragtning. Forekomsten i brandlaget af sand, grus og småsten samt af jordstængler m.m. fra visse planter, hvoraf ingen af delene normalt findes i husdyrgødning, viser imidlertid, at der er tale om tørv, der er anvendt som brændsel ved ligbrændingen.

Dette er er det hidtil ældste kendte eksempel på brug af tørv som brændsel i dansk oldtidshistorie, og fundet rykker vidnesbyrdene om tørvegravning i Danmark adskillige hundrede år tilbage, fra forromersk jernalder til slutningen af ældre bronzealder (Becker 1948, 92ff) (6).

\section{Pollenanalytiske undersegelser}

Der blev foretaget en pollenanalyse af en prøve af brandlaget i ligbrændingsgruben. Prøven viste sig imidlertid kun at indeholde brændt plantevæv og nogle fă, varmedeformerede pollen af hassel og birk.

Ved udgravningen blev endvidere som led i Thy Projektet udtaget jordprøver til pollenanalyse fra højfylden og det gamle muldlag under højen (fig. 6 p1-p4). Alle pollenanalyser blev foretaget af Sv. Th. Andersen, DGU, se appendix 4 s. 193 (Andersen 1994; 1995).

Resumé af undersøgelsesresultatet: Analyserne viste lave frekvenser for træpollen fra alle prøverne, fra 2,9 til 12\% af samtlige pollen. Fire træarter var repræsenterede: Lind, hassel, birk og el, hvoraf lind og el var de talrigeste. En del af disse træpollen skal antagelig opfattes som stammende fra tidligere tiders bevoksning på stedet.

Der fandtes høje frekvenser for græsser, fra 38 til 59\% af ikke-træpollen (NAP), højest i det gamle muldlag under højen, og ligeledes høje værdier for græsningsindikatoren lancetbladet vejbred, fra 34,4 til 51,9\% af NAP, højest i selve højfylden. Frekvensen af pollen fra planter knyttet til bar jord, som indicerer agerbrug - heriblandt kornpollen - var lille, fra 0,7 til 4,5\% af NAP. 
Pollenanalyserne viser, at Damsgårdhøjen blev opført i et åbent græsningslandskab, evt. med lidt kratbevoksning. Undersøgelsen viser endvidere, at græstørvene, der er brugt ved højens opførelse, er taget på et sted, der har været hårdere afgræsset end selve stedet, hvor højen blev opført. Tilstedeværelsen af barjordsplanter, omend i små mængder, viser at agerbrug fandt sted i begrænset omfang, hvilket bekræftes af tilstedeværelsen af ardspor under højen (fig. 3, forgrund).

\section{Konklusion}

Der kan på baggrund af det foregående ikke herske tvivl om, at gruben med brandlaget under Damsgårdhøjen er resterne af et ligbål, hvorpå en voksen kvinde i per. III af ældre bronzealder er blevet brændt, liggende i udstrakt eller let sammenbøjet stilling med hovedet mod nord. Efter ligbrændingens afslutning er størstedelen af knoglerne og gravgodset blevet indsamlet og placeret i en lille stenkiste, opbygget umiddelbart syd for ligbrændingsgruben. Derefter er en græstørvshøj rejst over stenkisten og resterne af ligbålet.

Det landskab, hvor begravelsen fandt sted, var åbent og meget træfattigt. Det er påfaldende, at der i de pollenanalytiske undersøgelser af såvel den gamle overflade under højen som af højfylden ikke fandtes pollen fra hverken ask eller bævreasp, der sammen med mosetørv var anvendt som brændsel ved ligbålet. Materialerne hertil må således være hentet i en vis afstand fra ligbræn-dingsgruben. Bævreasp kan vokse næsten hvor som helst, mens ask findes på muldrig, fugtig bund, ofte på vældbund og i ådale (7). Sådanne betingelser kan f.eks. have været tilstede omkring Hørsted $\AA$, der løber nogle hundrede meter øst og syd for Damsgårdhøjen. Hedemoser, hvor man har kunnet grave tørv, har uden tvivl også været at finde i de lavtliggende områder, der omgiver den landtunge højen ligger på.

Damsgårdfundet viser således, at tilsyneladende marginale lavtliggende og fugtige områder allerede i midten af bronzealderen, ligesom i nyere tid, har været vigtige kilder til brændsel i det åbne thylandske landskab.

\section{Parallelfund}

Den antropologiske undersøgelse af de brændte ben fra Damsgård gav det endelige bevis for samhørigheden mellem ligbrændingsgruben og stenkisten, og hermed står vi for første gang i det danske materiale fra ældre bronzealder med både resterne af et ligbål og den tilhørende begravelse.

En gennemgang af udgravningsberetninger samt af fundbeskrivelser i litteraturen, viser imidlertid, at der ikke er tale om et enkeltstående tilfælde. Tværtimod kan samtidige grave med tilhørende ligbrændingsgruber på baggrund af Damsgårdfundets ualmindelig klare vidnesbyrd nu påvises i flere tilfælde såvel i Thy som udenfor, nærmere bestemt på øen Sild i Vadehavet.

\section{Nørhå}

På Nørhågårds Mark, Nørhå sogn, undersøgtes i 1982 tomten af en helt bortpløjet høj, sb.nr. 78, Nørhå sogn (8). Der fandtes ikke bevaret højfyld, men højens udstrækning blev angivet af et $16 \mathrm{~cm}$ tykt lag gråbrunt, humøst sand, 


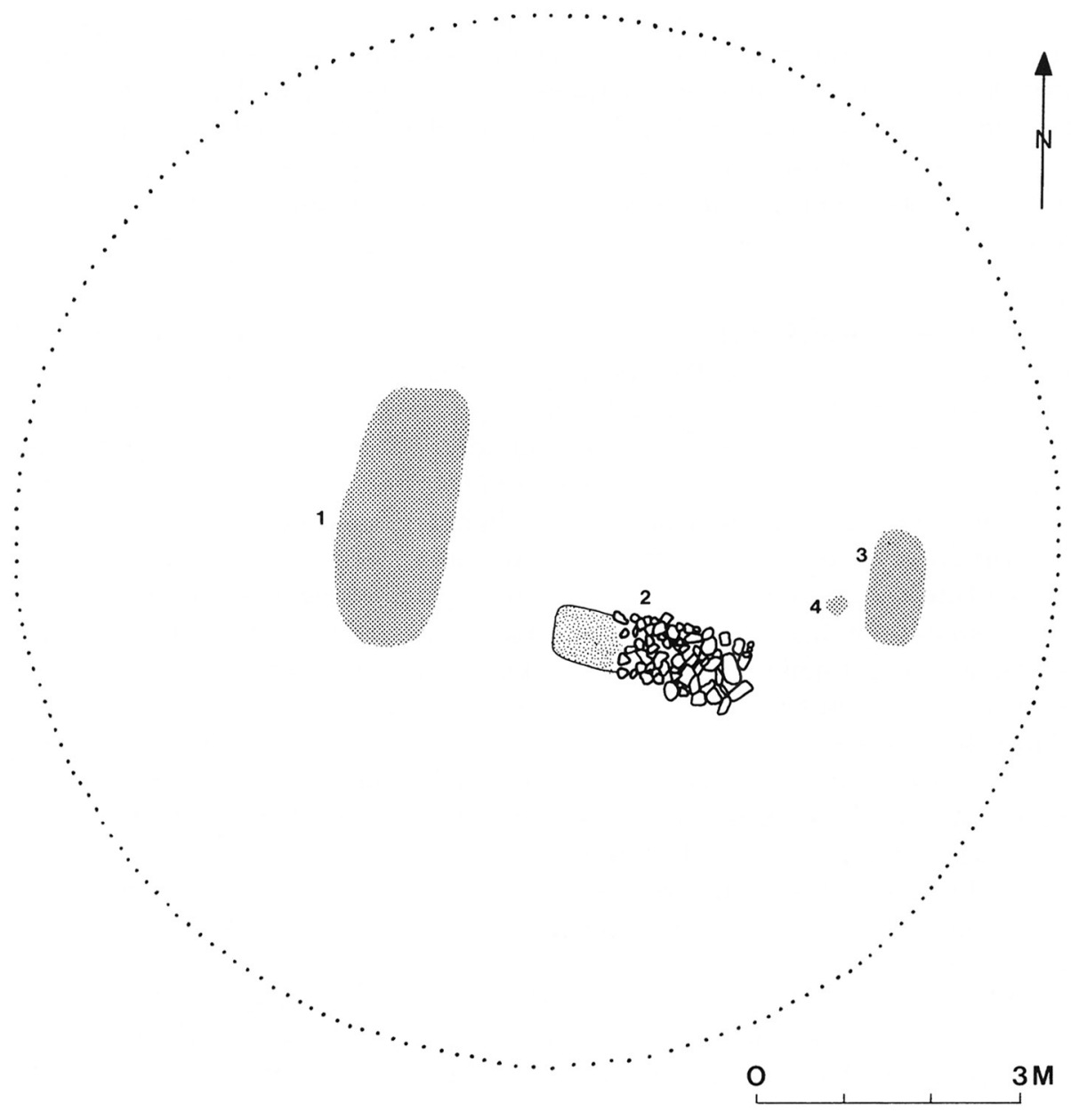

Fig. 16. Overpløjet høj fra Nørhå. Plan. 1-4: Grave.

Ploughed-over burial mound from Nørhå. Plan. 1-4: Grave.

antagelig for størstedelen bestående af det gamle muldlag. Laget sås i fladen som en lys plet, ca. $12 \mathrm{~m}$ i diam., omgivet af brunsort sand, der tolkedes som en begyndende podsolering i området uden for højen (fig. 16). Der fandtes i alt 4 grave, hvoraf ingen indeholdt daterende oldsager (9).

Den her omhandlede grav, grav 2, kan være primærgraven, men det kan ikke afgøres med sikkerhed. Graven lå umiddelbart $S \varnothing$ for højcentrum og sås efter afrømning af pløjelaget som en 1,8x0,9 $\mathrm{m}$ stor, rektangulær stenlægning, orienteret $\varnothing S \varnothing-V N V$. Under stenlægningen fremkom en kiste af kalkstensbleger, $1,1 \times 0,4 \mathrm{~m}$ og ca. $0,25 \mathrm{~m}$ dyb. Kisten var nedsat $\mathrm{i}$ et fyldskifte med gråbrun, sandet fyld, der var gravet $30 \mathrm{~cm}$ ned i undergrunden. I kisten fandtes en samling brændte ben på en bundbelægning af kalkstensbleger (fig. 17b). 


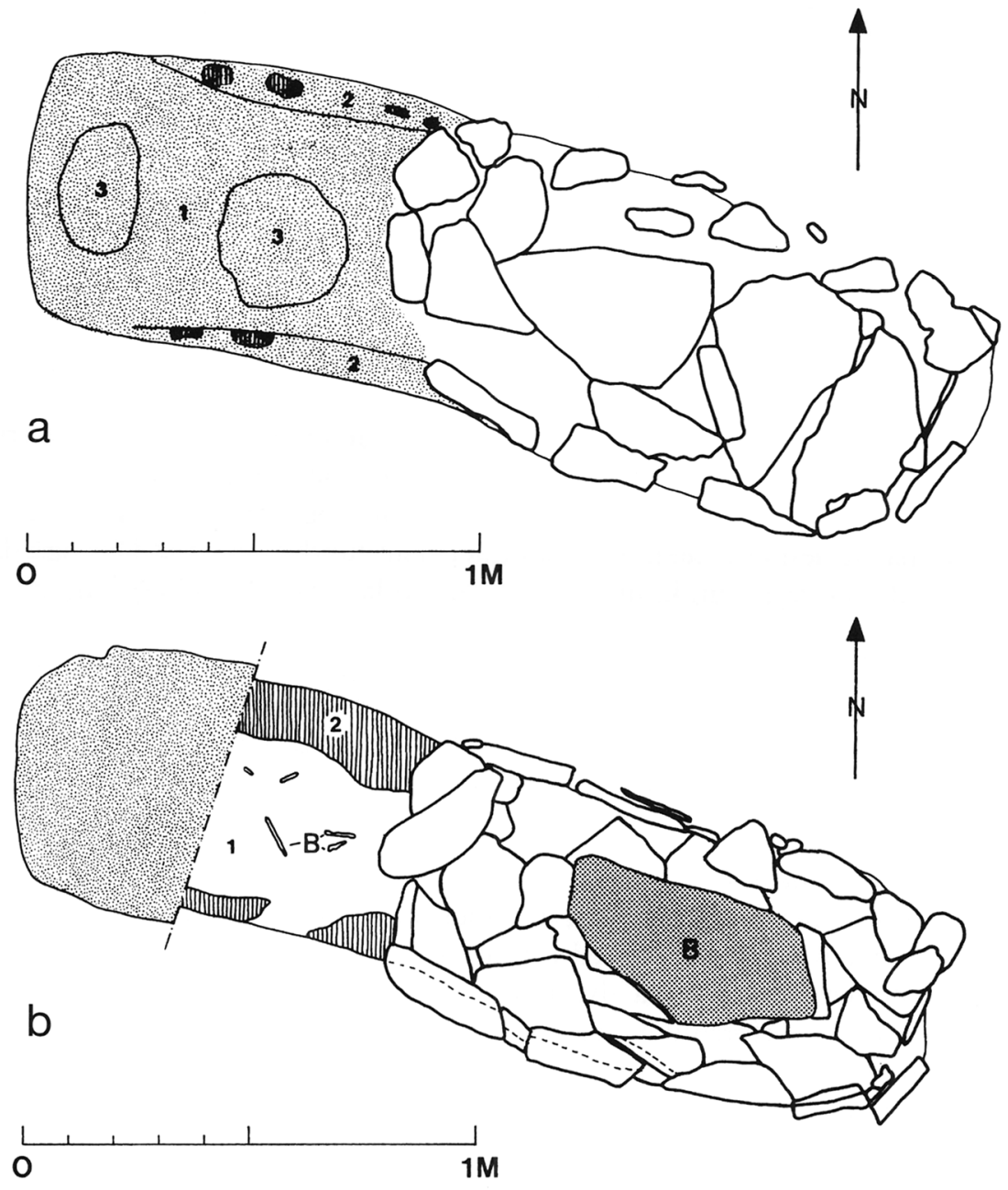

Fig. 17a-b. Stenkiste og tilhørende grube fra Nørhå i to forskellige udgravningsstadier.

Stone cist and accompanying pit from Nørhå at two stages of the excavation.

17a. 1: Gråbrunt sand. 2: Rødbrændt sand med trækulsholdige partier. 3: Gråbrunt heterogent sand iblandet gulbrune til mørkbrune sandpartier. Muligvis forstyrrelse.

1: Greyish-brown sand. 2: Reddish burnt sand with charcoal-rich areas. 3: Greyish-brown heterogeneous sand mixed with yellowish-brown to dark brown sandy patches. Possible disturbance.

17b. 1: Rødbrunt leret sand med brændte ben. 2: Sort, fedtet trækulsholdig fyld næsten uden brændte ben. B: Brændte ben.

1: Reddish-brown clayey sand with burnt bone. 2: Black, greasy charcoal-rich layer virtually lacking fragments of burnt bone. B: Burnt bones.

I undergrundsniveau i direkte forlængelse af kisten mod VNV sås et afrundet rektangulært fyldskifte, $0,8 \mathrm{x} 0,6 \mathrm{~m}$, med fyld af gråbrunt sandmuld afgrænset i hver side af en stribe rødbrændt, sandet fyld med sorte, trækulsfarvede pletter (fig. 17-18). 
I snit viste fyldskiftet sig at have en trugformet bund og være gravet $17 \mathrm{~cm}$ ned i undergundssandet (fig. 19). Langs siderne og bunden sås et ca. $5 \mathrm{~cm}$ tykt lag af sort, fedtet, stærkt trækulsholdig fyld med et par enkelte stykker brændte knogler. Over dette lag sås rødbrændt let fedtet sand med spredte stykker brændt ben. Som en fordybning i dette lag sås gråbrun sandmuld, der muligvis skyldes en forstyrrelse foregået samtidig med bygningen af stenkisten. Et område med sort og rødbrændt fyld i overfladen af det gamle muldlag tæt vest for kisten kan ligeledes forklares som resultat af aktiviteter $\mathrm{i}$ forbindelse med begravelsen.

Anlægget tolkedes ved udgravningen som en normal stenkiste fra bronzealderens midte, hvortil der var knyttet en grube, som var fyldt op med materiale fra ligbålet. Gruben blev ikke opfattet som selve ligbrændingspladsen, eftersom der $\mathrm{i}$ undergrundssandet $\mathrm{i}$ bunden ikke kunne ses spor efter ildpåvirkning. Fyldens udprægede lagdeling, der følger grubens bund og sider (jvnf. fig. 19), tyder dog ikke på, at den er omlejret, og anskuer man fundet i lyset af Damsgårdgraven, hvor der i øvrigt kun kunne konstateres rødfarvning af undergrunden i visse partier af gruben, er lighederne iøjnefaldende: I begge tilfælde er gruben placeret i nær sammenhæng med en stenkiste, og i begge tilfælde er gruben "foret" med et sort, fedtet brandlag over hvilket der ses rødlig fyld med brændte ben. Det var håbet, at en analyse af de brændte knogler fra henholdsvis gruben og stenkisten ville give et bevis for samhørigheden, som tilfældet var ved Damsgård.

\section{Analyse af de brondte ben}

De brændte knogler fra selve kisten stammer fra en yngre, voksen person på 1835 år. Der er en vis sandsynlighed for, at der er tale om en kvinde. Blandt de brændte knogler fandtes også dyreknogler. De fleste af knoglerne var hvidbrændte, enkelte sortbrændte, men der kan ikke udfra dette siges noget om ligets stilling på ligbålet.

De brændte knogler fra gruben omfattede ligeledes såvel menneske- som dyreknogler. Der kunne ikke påvises direkte samhørende knogler fra gruben og stenkisten, som tilfældet var ved Damsgård, men der er intet, som taler imod, at der kan være tale om knogler fra samme person, ligesom også brændingsgraden ser ud til at have været den samme (10).

\section{Konklusion}

I lyset af ovenstående opfattes graven fra Nørhå som et anlæg af samme karakter som graven fra Damsgård. Dette baseres forst og fremmest på gentagelsen af kombinationen stenkiste + grube med brandmateriale, sammenholdt med resultatet af den antropologiske undersøgelse af de brændte knogler. De to gravanlæg er dog ikke identiske: I Damsgård fandtes ligbålsmateriale i kisten, hvilket ikke var tilfældet i Nørhå. Gruben ved Nørhå er desuden langt mindre end ved Damsgård og har i modsætning til denne direkte forbindelse med fyldskiftet omkring stenkisten. Endelig fandtes ingen spor efter ildpåvirkning af grubens bund ved Nørhå, som tilfældet var ved Damsgård.

De to sidst anførte forskelle kan forklares ved, at stenkisten i Nørhå er anlagt oven i den østlige del af gruben, således at kun grubens vestende, hvor ildpåvirkningen kan have været mindre kraftig, er bevaret urørt. Gruben i 
Fig. 18. Gruben fra Nørhå i udgravningsstadium svarende til tegningen fig. 17a.

Pit from Nørhå at the stage of the excavation corresponding to the drawing in fig. 17a.

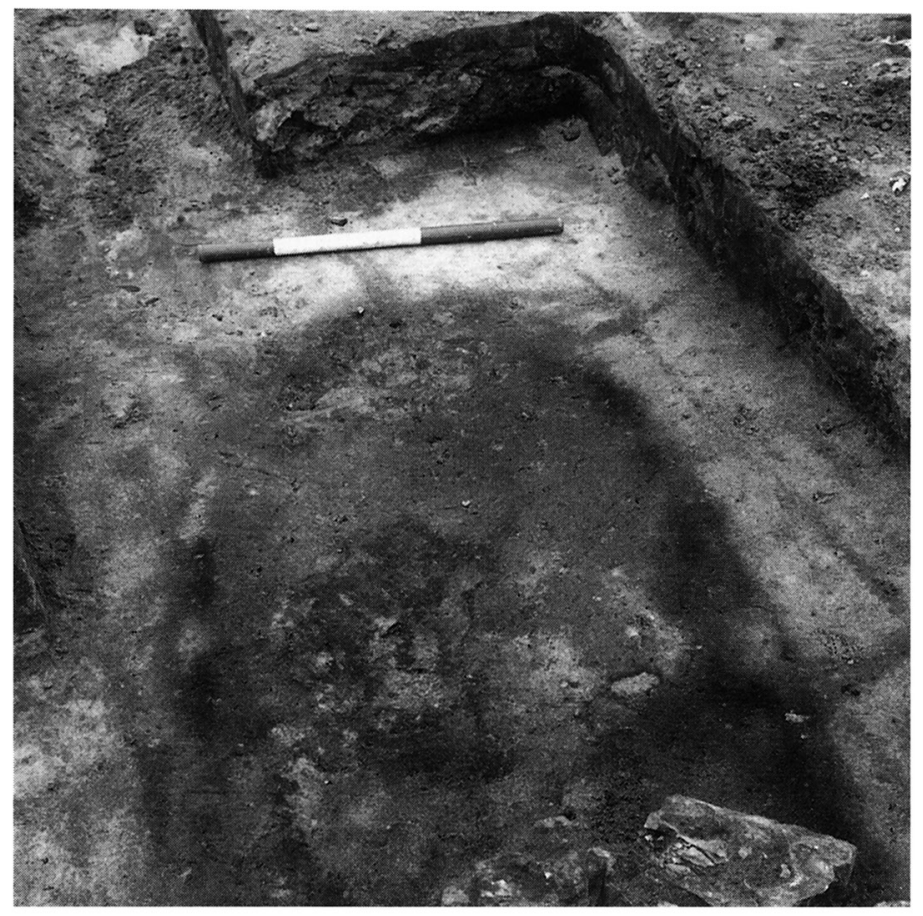

Fig. 19. Snit af gruben fra Nørhå.

Section through the pit at Nørhå.

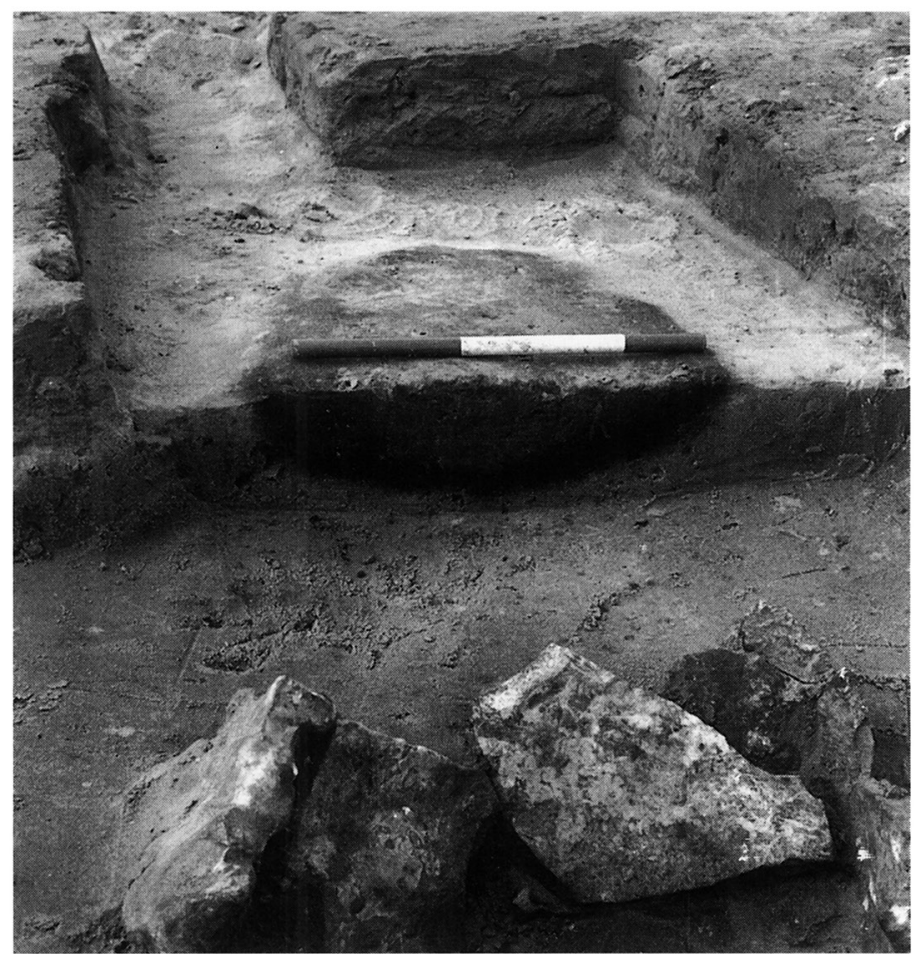


Nørhåanlægget tolkes derfor som en regulær ligbrændingsgrube af samme art som ved Damsgård. Eftersom der ikke fandtes daterende oldsager, kan det om Nørhågravens datering blot siges, at selve gravformen - en ca. $1 \mathrm{~m}$ lang kalkstenskiste med brændte ben - placerer graven i bronzealderens midte, og derved nogenlunde samtidig med Damsgård.

\section{Villerup}

I 1981-1982 undersøgtes i Villerup, i den sydvestlige del af Thy, en stærkt kreaturbeskadiget høj, sb.nr. 86, Vestervig sogn (11). Trods sin stærkt ødelagte tilstand viste højen sig at indeholde 6 velbevarede stenkister fra ældre bronzealder, fordelt på 5 højfaser (fig. 20). Kun de tre ældste grave skal behandles i denne sammenhæng (12).

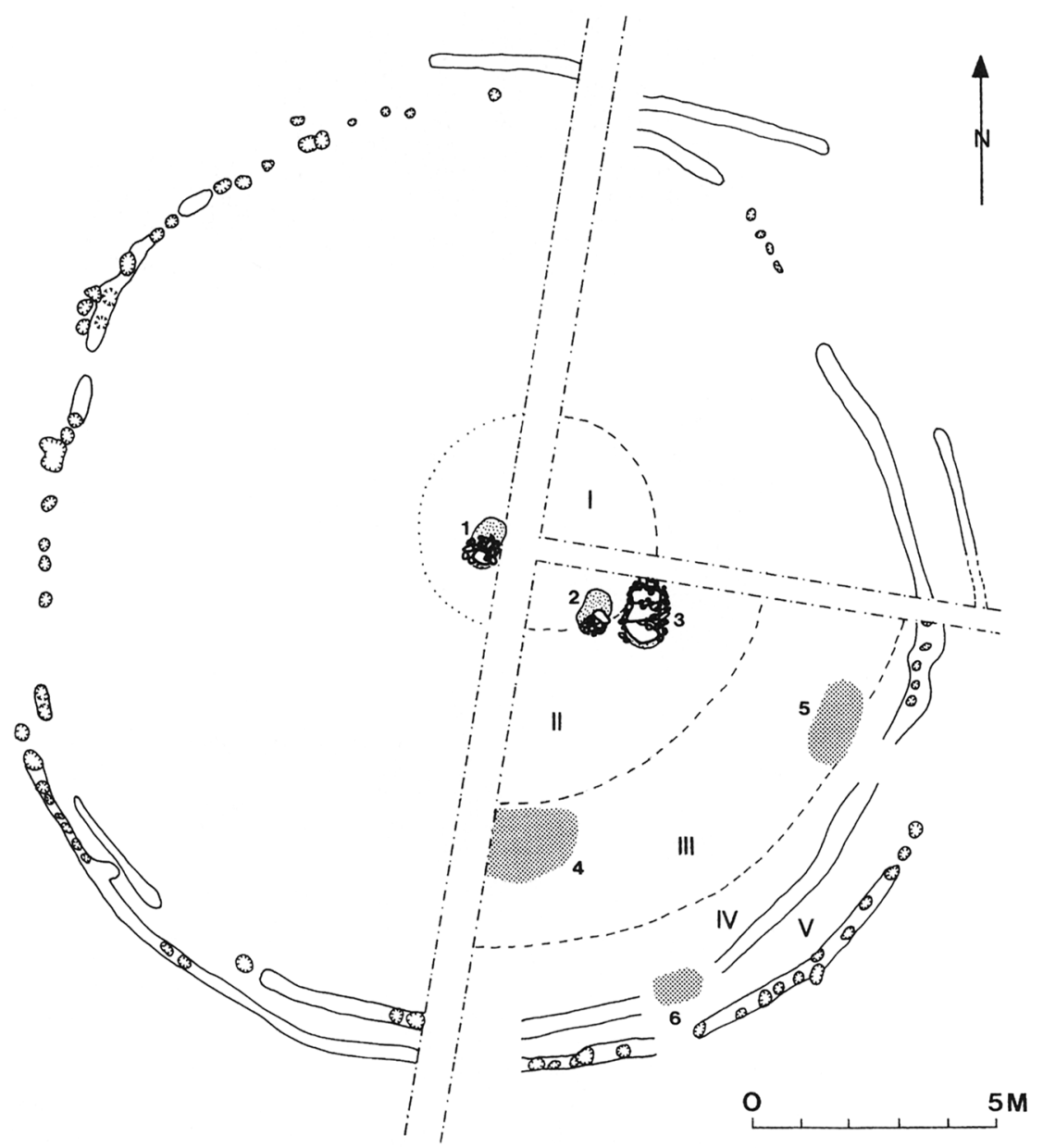

Fig. 20. Gravhøj fra Villerup. Plan. 1-6: Grave. I-V: Højfaser.

Burial mound from Villerup. Plan. 1-6: Grave. I-V: Barrow phases. 
Fig. 21. Grav 1 fra Villerup set fra nord. Bemærk kanten af gruben i forgrunden. Foto: Per Orla Thomsen.

Grave 1 from Villerup seen from the north. Notice the edge of the pit in the foreground.
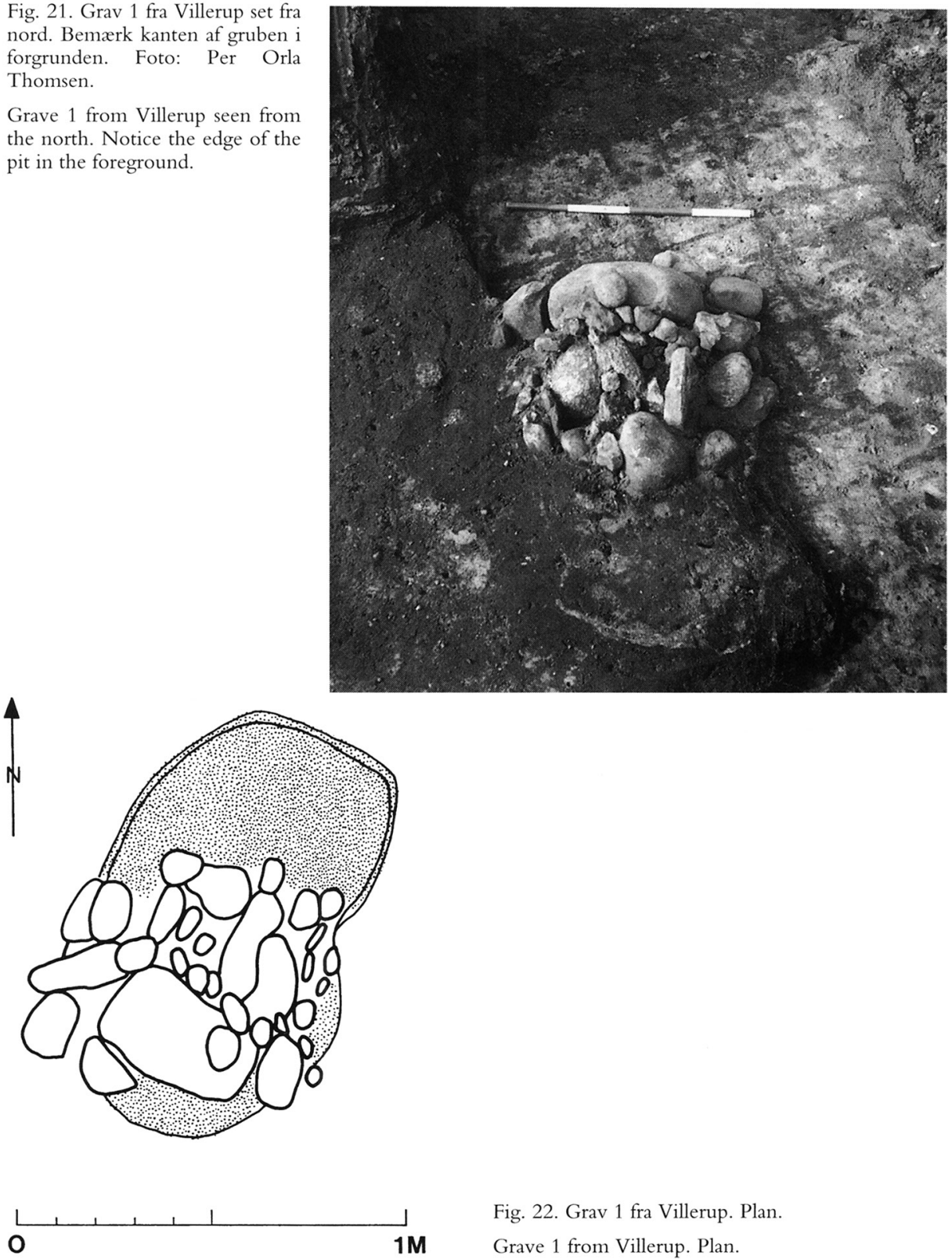

Fig. 22. Grav 1 fra Villerup. Plan. Grave 1 from Villerup. Plan.

\section{Høifase}

Primærgraven, grav 1, var en lille, uregelmæssig stenkiste, 0,3×0,2 m i indvendige mål, kun med 1 dæksten (fig. 21-22). Siderne bestod af 1 større gavlsten i syd, 3 mindre sidesten og i nordenden 2 hovedstore sten. Bunden var brolagt med håndstore marksten, hvorpå der lå et tyndt lag brændte knogler. Sammen med disse fandtes et stykke tekstil og en bronzetutulus, fig. 23, som daterer graven til periode II af ældre bronzealder (13). 

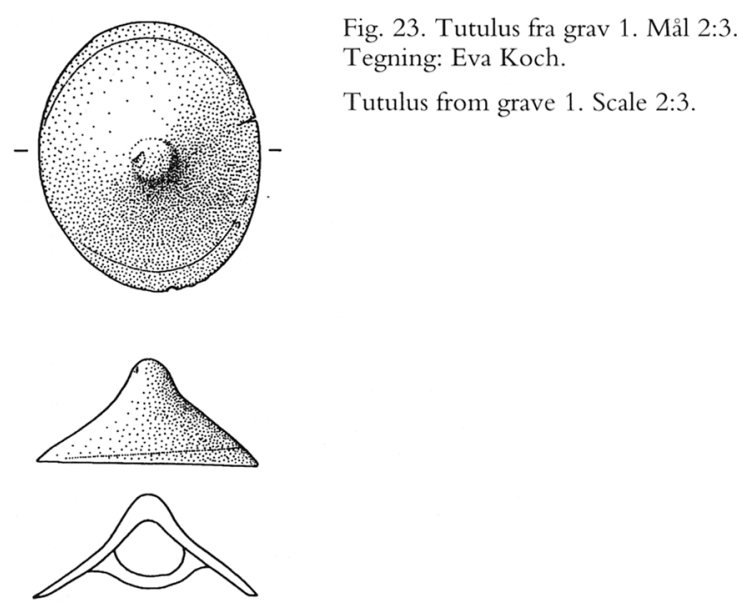

Over graven var rejst en ganske lille høj, 0,5 $\mathrm{m}$ høj og 4,1 $\mathrm{m}$ i diam. Stenkisten var anlagt i sydenden af et ovalt fyldskifte, $1,1 \times 0,6 \mathrm{~m}$, orienteret NNØ-SSV (fig. 22). Fyldskiftets omrids markeredes af en tynd stribe lysgult til rødgult leret sand, der stod klart mod det forhistoriske muldlag, og det var nedgravet gennem dette indtil $10 \mathrm{~cm}$ ned i undergrunden. Fylden bestod af vekslende, humøse lag, hvoraf nogle indeholdt trækul i form af større stykker såvel som små pletter. Bunden i fyldskiftet viste pletvis rødfarvning af undergrundssandet som følge af varmepåvirkning. (Efter udgravningsberetning ved Per Orla Thomsen).

Analyse af de brandte ben

De brændte knogler fandtes udelukkende i selve stenkisten. De viste sig ved analyse at stamme fra et spædbarn på $10 \mathrm{mdr}$., \pm 3 mdr. d.v.s. mellem 7 og 13 måneder gammelt. Endvidere fandtes fire fragmenter af en mellemfodsknogle fra får eller ged, der viste små huller, antagelig gennemboringer. Tolkningen af stykket er uvis (14).

\section{Hoifase}

Højens 2. fase bestod af en tørveopbygget høj, der var $8,5 \mathrm{~m}$ i diam. og $1,3 \mathrm{~m}$ høj. Den dækkede den lille høj med primærgraven samt to sekundære grave, grav 2 og grav 3, der var gravet ned i kanten af den første høj, antagelig på samme tid.

Grav 2 fremstod som et ovalt fyldskifte, 1,0x0,6 m, med orientering N-S. Dets afgrænsning i fladen markeredes af en $1 \mathrm{~cm}$ bred, trækulsholdig stribe og inden for denne en $1 \mathrm{~cm}$ bred stribe af gulligrødt til hvidgult, sandet ler, der ved undersøgelsen blev tolket som værende ildpåvirket (fig. 24-25). I snit sås en fladbundet grube, ca. $15 \mathrm{~cm}$ dyb, hvis bund og sider blev dannet af det tynde, sorte trækulsholdige lag med det gulrøde, antagelig brændte, sandede lerlag over (fig. 26). I det rødgule lag sås adskillige stykker trækul, dels som runde, pindelignende, dels som flade, mere bræddelignende stykker. Langs sydsiden sås en del større, skråtstillede trækulsstykker, men noget system kunne ikke erkendes. Omtrent midt $\mathrm{i}$ gruben stod en lodretstillet sten, $0,2 \times 0,4 \mathrm{~m}$, og syd herfor, 
Fig. 24. Grav 2 fra

Villerup set fra vest.

Kanten af gruben fremstår

tydeligt. Foto: Jacob

Vedsted.

Grave 2 from Villerup seen from the west. The edge of the pit can be clearly seen.
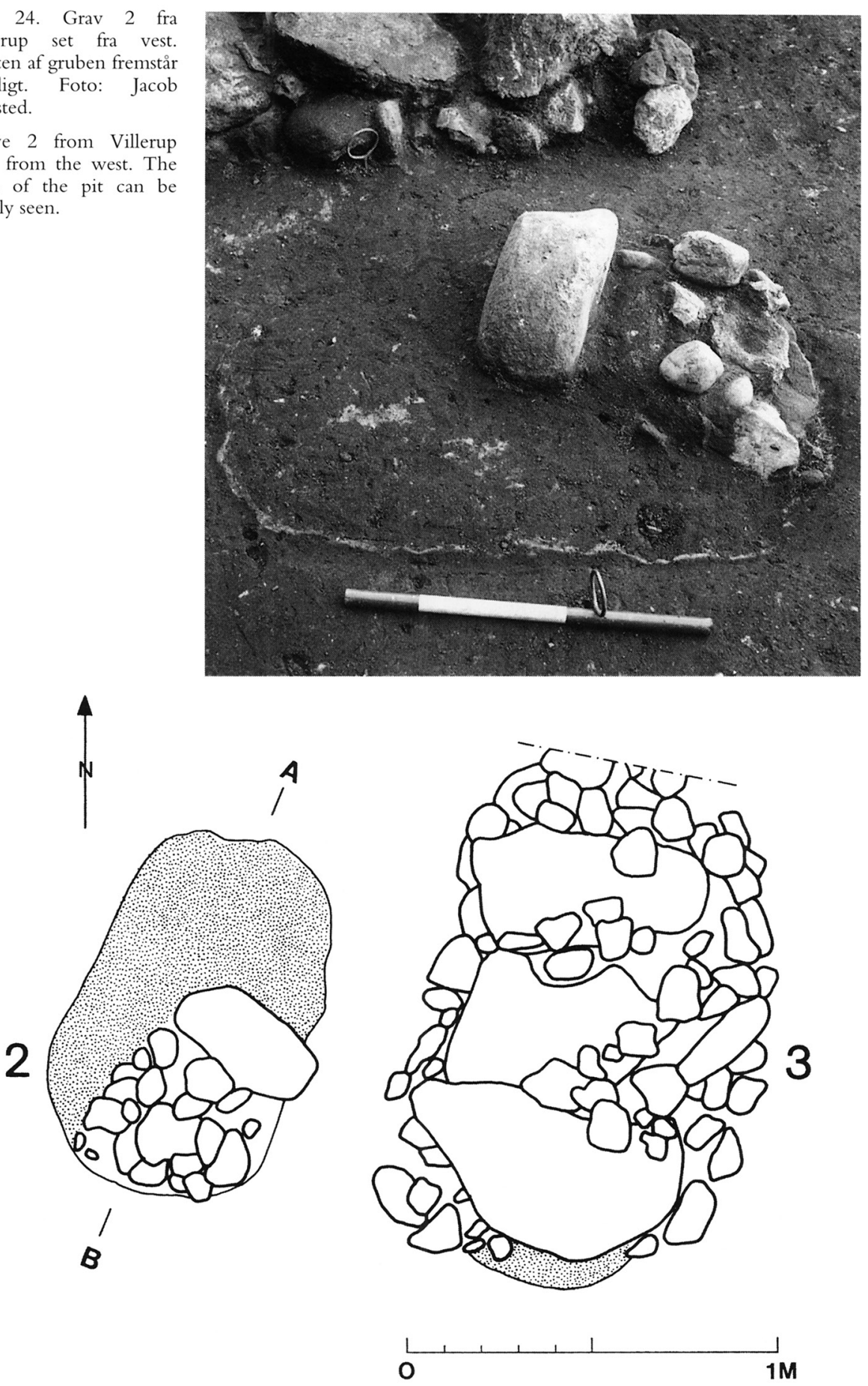

Fig. 25. Grav 2 og 3 fra Villerup. Plan.

Graves 2 and 3 from Villerup. Plan. 
udfyldende grubens S $\varnothing$-lige fjerdedel, fandtes en samling mindre sten uden en egentlig kisteopbygning. Under denne stensamling stod et lille lerkar (fig. 27), og mellem dette og den store sten fandtes en lille plet af meget små stykker brændte knogler. Lerkarret indeholdt kun jord, og der fandtes ikke andre daterende genstande. (Efter udgravningsberetning ved Jakob Vedsted).

Graven må dateres til ældre bronzealder og kan ud fra stratigrafiske forhold siges at være yngre end grav 1, men ikke senere end periode III. Dette stemmer med dateringen af lerkarret fig. 27, idet den lodrette rand, det blødt afrundede og højtsiddende bugknæk og den markerede bund med afsat fod tilsammen bedst kan henføres til den mellemste del af ældre bronzealder - per. II/III - svarende til M. Rasmussens fase 3a (Rasmussen 1993, 124ff).

Tæt øst for grav 2 og liggende parallelt med denne fandtes grav 3, en lille, rektangulær stenkiste på $0,75 \times 0,35 \mathrm{~m}$ og $0,35 \mathrm{~m}$ dyb med tre dæksten (fig. 25 og 28-30). I kisten fandtes et $15 \mathrm{~cm}$ tykt lag af indskredet eller indsivet materiale over bunden, der bestod af et lag spredte småsten. Herpå lå en koncentration af brændte knogler og en bøjlenål af bronze med riflet bøjle og spiralender, der kun er bevaret indstøbt i paraffin. Bøjlenålens hoved er ikke bevaret, men graven skal efter alt at dømme dateres på linje med grav 2.

Kisten var nedsat $\mathrm{i}$ en lav grube, hvoraf kun en meget lille del stak uden for kistens sydende (fig. 28). Gruben var af samme karakter som ved grav 2 med et få cm tykt, gulrødt, sandet, antagelig brændt, lag i bunden under den stenlagte kistebund. I det gulrøde lag sås ligesom ved grav 2 sorte partier med trækul og lidt brændt flint (fig. 30). (Efter udgravningsberetning ved Jakob Vedsted).

\section{Analyse af de brondte ben fra grav 2}

De brændte ben fra grav 2 viste sig at stamme fra et spædbarn på 8-12 måneder, d.v.s. nogenlunde af samme alder som barnet i grav 1 (15).

De brændte knogler fra grav 3 har ikke kunnet analyseres, da de blev sammenblandet med knoglerne fra flere andre grave under en orkanagtig storm, hvor skurvognen væltede. Det lader sig derfor heller ikke afgøre, hvilket forhold der kan have været mellem de to individer, der formentlig er gravlagt samtidig. Herpå tyder dels de stratigrafiske forhold i højen, dels gravenes beliggenhed tæt sammen og med samme længderetning.

\section{Konklusion}

De tre ældste grave i Villeruphøjen viser en række påfaldende indbyrdes ligheder: Alle tre er stenbyggede anlæg, spændende fra en egentlig kiste til en "gavlsten" med en stendynge foran, og alle tre er anlagt i en lav, fladbundet grube, hvis afgrænsning i fladen fremstod som et tyndt, gulligrødt, antagelig brændt, ler/sandlag (tørveaske?) i forbindelse med hvilket der ved grav 2 og 3 fandtes trækul. I grav 1 kunne der direkte iagttages rødbrændte partier i det gule undergrundssand i bunden af gruben.

Grav 1 og 2, hvor stenkisten/stensamlingen kun udfyldte en del af gruben, rummede begge knogler af spædbørn, højst ét år gamle. Ved grav 3 havde stenkisten næsten udslettet sporene af gruben, muligvis er der her tale om et ældre barn eller en voksen. Forekomsten af rødbrændt undergrundssand i grav 1 viser, at der her må have været tændt bål, hvilket også de rødbrændte lerlag ved grav 2 og 3 viser. 


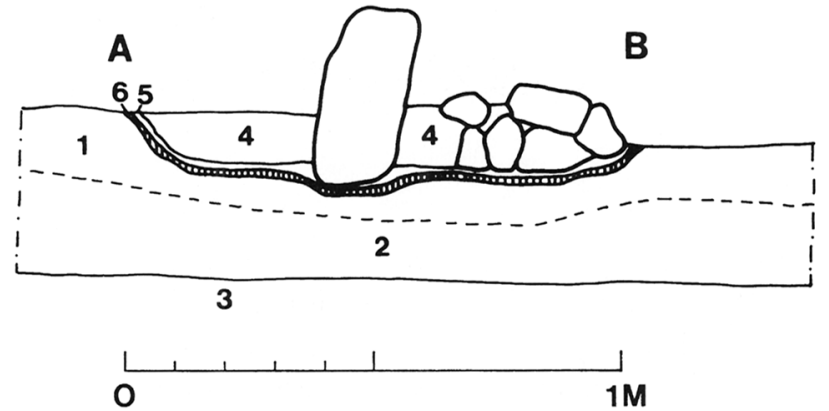

Fig. 26. Snit A-B af grav 2. 1: Mørk leret sand. Højfyld. 2: Meget lig lag 1, men noget mere gulspættet. 3: Gulligt leret sand. Undergrund med ardspor øverst i laget. 4: Mørkt gråligt leret sand. 5: Gullig-rødt til hvidgult, antagelig brændt, sandet ler. $6: 1 \mathrm{~cm}$ bred trækulsholdig stribe. Beskrivelse efter udgravningsberetning ved Jacob Vedsted.

Section A-B through grave 2. 1: Dark clayey sand. Mound fill (core). 2: Very like layer 1, but more flecked with yellow. 3: Yellowish clayey sand. Sub-soil with ard marks uppermost in the layer. 4: Dark greyish clayey-sand. 5: Yellowish-red to whitish-yellow, presumably burnt, sandy clay. $6: 1 \mathrm{~cm}$ thick charcoal stripe. Descriptions after Jacob Vedsted's excavation report.
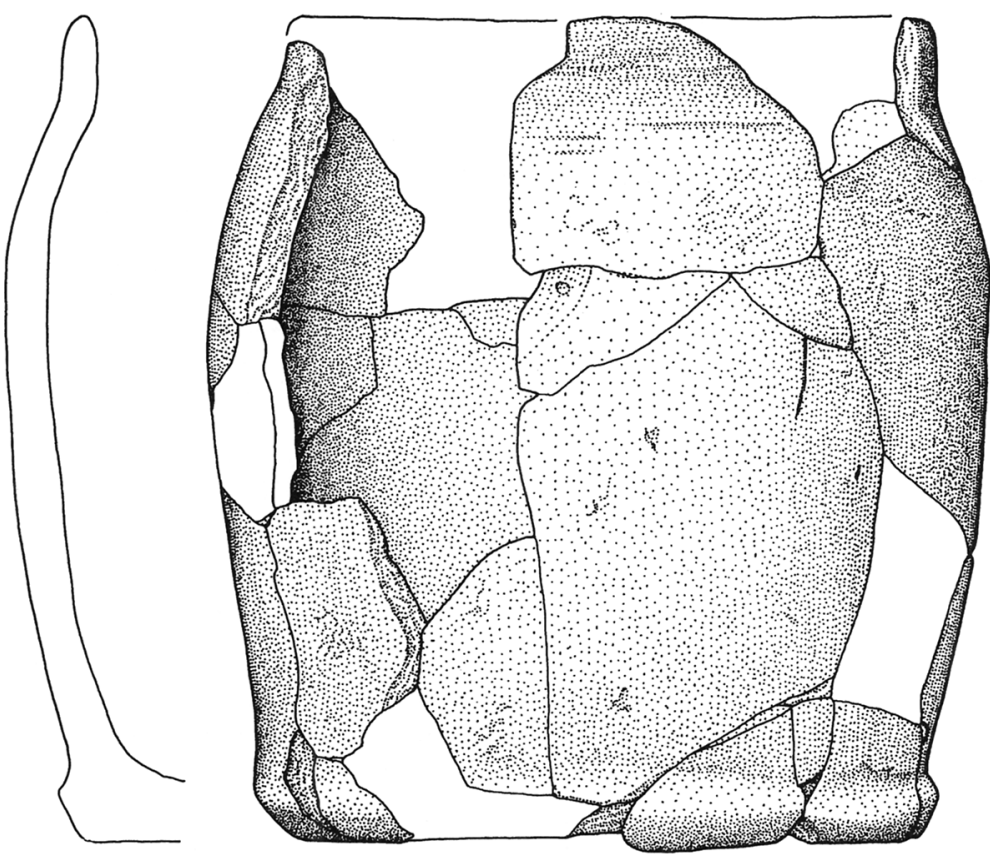

Fig. 27. Lerkar fra grav 2. Mål 2:3. Tegning: Eva Koch.

Vessel from grave 2. Scale 2:3. 


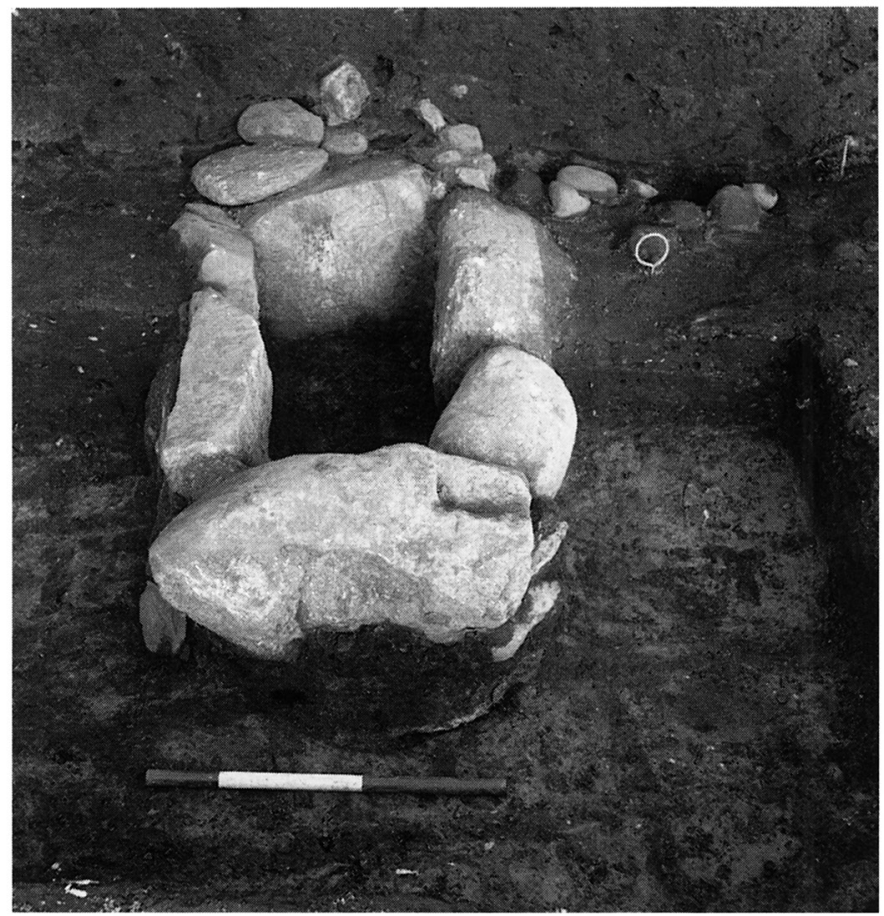

Fig. 28. Grav 3 fra Villerup. I forgrunden bagved målestokken ses kanten af gruben. Foto: Jacob Vedsted.

Grave 3 from Villerup. The edge of the pit can be seen in the foreground behind the scale.

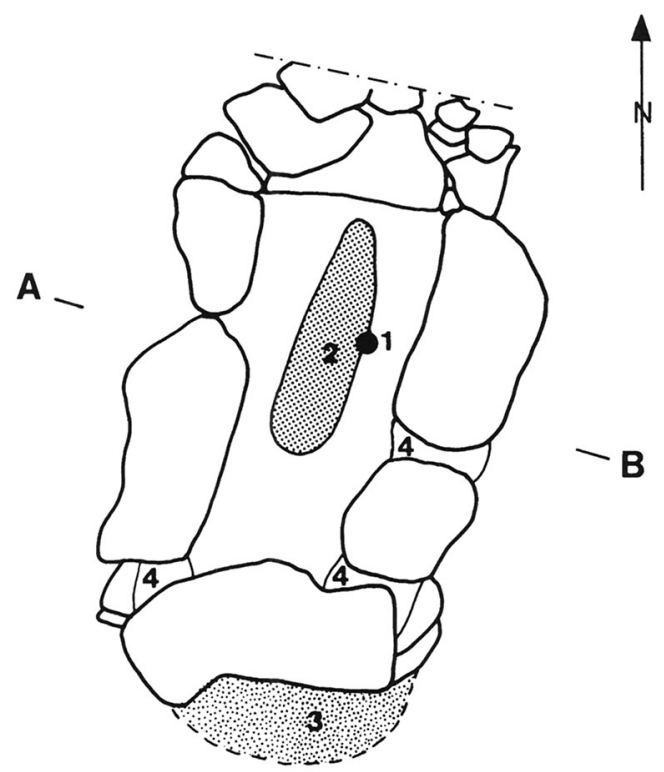

Fig. 29. Grav 3 fra Villerup. 1: Bøjlenål af bronze. 2: Brændte ben. 3: Grube. 4: Lerpakning.

Grave 3 from Villerup. 1: Bronze fibula. 2: burnt bone. 3: Pit. 4: Clay from the seal of the cist.

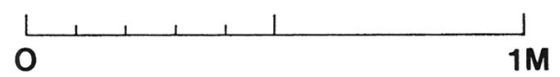




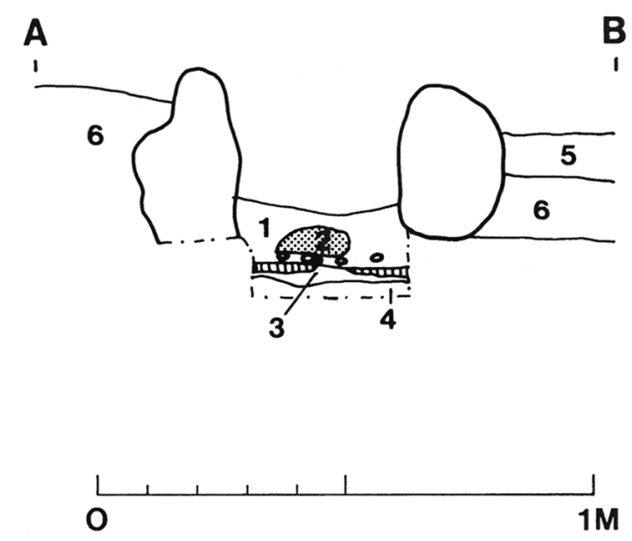

Fig. 30. Snit A-B af grav 3. 1: Løst gulligt og sortspættet leret sand med enkelte klumper af hvidgult ler fra pakningen af kisten og enkelte spredte brændte ben. 2: Koncentration af brændte ben ovenpå et lag småsten. 3: Gul-rødt sandet lag. Antagelig brændt. Heri sorte partier med enkelte stykker trækul og lidt brændt flint (lodret skraveret). 4: Gult leret sand. Undergrund med ardspor. 5-6: Højfyld.

Section A-B through grave 3. 1: Loose yellowish and blackish-flecked clayey sand with occasional clumps of whitish-yellow clay from the seal of the cist plus occasional burnt bone. 2: concentration of burnt bone over a layer of small stones. 3: Yellowish-red sandy layer, presumably burnt. Includes areas with occasional fragments of charcoal and a little burnt flint (vertical hatching). 4: Yellowish clayey sand. Sub-soil with ard marks. 5-6: the fill (core) of the mound.

Ud fra Damsgårdfundet er det nærliggende at tolke gruberne i Villeruphøjen som egentlige ligbrændingsgruber, i hvilke man efter en optømning af ligbålsresterne har anlagt en stenkiste til opbevaring af de brændte ben. Placeringen af stenkisten oven i selve ligbrændingsgruben genfindes delvis ved graven fra Nørhå (ovenfor).

Ved grav 1 og 2 kan de døde dermed siges at være brændt i hver sin lave, fladbundede grube på henholdsvis $1,1 \times 0,35 \mathrm{~m}$ og $0,95 \times 0,65 \mathrm{~m}$. Grubernes ringe størrelse kan forklares med, at der i begge tilfælde er tale om spædbørn. Størrelsen af gruben i grav 3 kan ikke afgøres, da kisten har forstyrret omridset, men den kan maksimalt have haft kistens ydre mål + den lille rest i sydenden, d.v.s. $1,4 \times 0,7 \mathrm{~m}$.

\section{Parallelfund uden for Thy}

I E. Aner og K. Kerstens værk "Die Funde der älteren Bronzezeit des Nordischen Kreises« findes i bd. 5, der omhandler fund fra Nordfriesland, to grave fra øen Sild, der viser stærke ligheder med de thylandske grave med ligbræn-dingsgruber (16).

\section{Keitum}

Aner \& Kersten, bd. 5 fund nr. 2707: En overpløjet høj ved Keitum, delvis ødelagt ved ældre gravninger. Her fandtes i 1939, 6,5 m SV for højmidten, en grav i form af en afrundet rektangulær grube, $2,5 \mathrm{~m}$ lang og $0,7 \mathrm{~m}$ bred, orienteret NV-S $\varnothing$ og nedgravet i undergrund. 


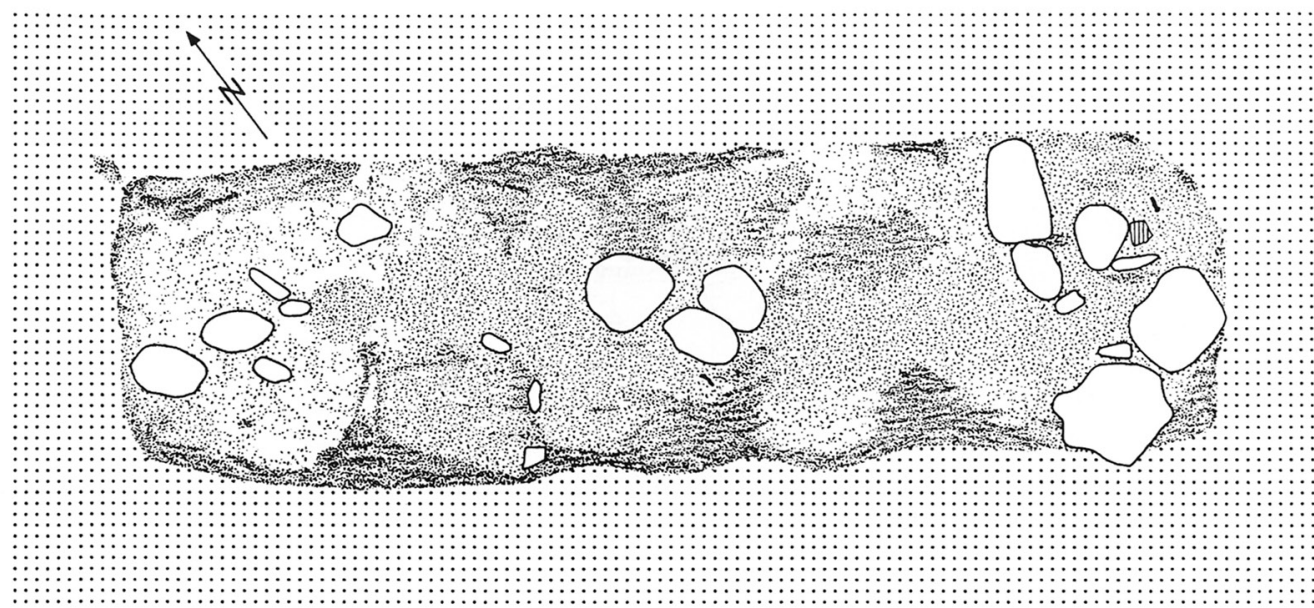

W. Erdverfärbungen mit Holzkohle

:::!: gewachsener Boden

\section{- Leichenbrand}

(1) Scherbe
0

$0,5 \mathrm{~m}$

Fig. 31. Gravfund fra Keitum, Sylt-Ost. (Efter Aner \& Kersten 1973-1990 bd. 5).

Grave from Keitum, Sylt-Ost. (After Aner \& Kersten, 1973-1990 vol. 5).

Fylden i gruben bestod langs siderne og i den nedre del af trækulsholdig fyld, der på tegning og udgravningsfoto tydeligt ses at danne smalle "faner" mellem firkantede, lyse partier på 30-35 cm’s bredde (fig. 31). Dette svarer nogenlunde til målene på de græstørv, der var lagt ned oven i brandlaget i ligbræn-dingsgruben fra Damsgård, og der kan ikke være tvivl om, at vi i Keitum har endnu et eksempel på dette fæenomen, hvor de sorte faner er brandlaget, der er presset op mellem græstørvene, hvilket også kunne iagttages ved Damsgård. I modsætning til Damsgård fandtes der øverst i gruben ved Keitum også en del knytnæevestore og større sten.

Tæt over gravbunden fandtes talrige trækulsstykker og små stykker af brændt lyng, og grubens bund var rødbrændt. I NV-enden lå en ophobning af brændte knogler fra et voksent individ og herimellem en glat, lukket bronzefingerring med en fastsiddende knogle samt flere skår, bl.a. et med vandret grebtap. Graven dateres til ældre bronzealder.

\section{Wenningstedt}

Aner \& Kersten, bd. 5 fund nr. 2766: To tætliggende høje, imellem hvilke der fandtes en fladmarksgrav $i$ form af en afrundet rektangulær grube, $2,10 \mathrm{~m}$ lang og $0,75 \mathrm{~m}$ bred, orienteret $\varnothing-\mathrm{V}$ og nedgravet til $0,55-0,60 \mathrm{~m}$ under jordoverfladen. I et dybere niveau målte gruben $1,8 \times 0,6 \mathrm{~m}$, og vestenden dannede nær gravbunden en lige linje (fig. 32).

Fylden i gruben bestod ifølge beskrivelsen af fint, gulbrunt sand med talrige små og enkelte store trækulsstykker på op til 1 m’s længde og $25 \mathrm{~cm}$ 's bredde. De store trækulsstykker lå tæt over gravbunden. I grubens østende stod en urne, der var omgivet af en lille stensætning og dækket af sten. I urnen, der var et lil- 


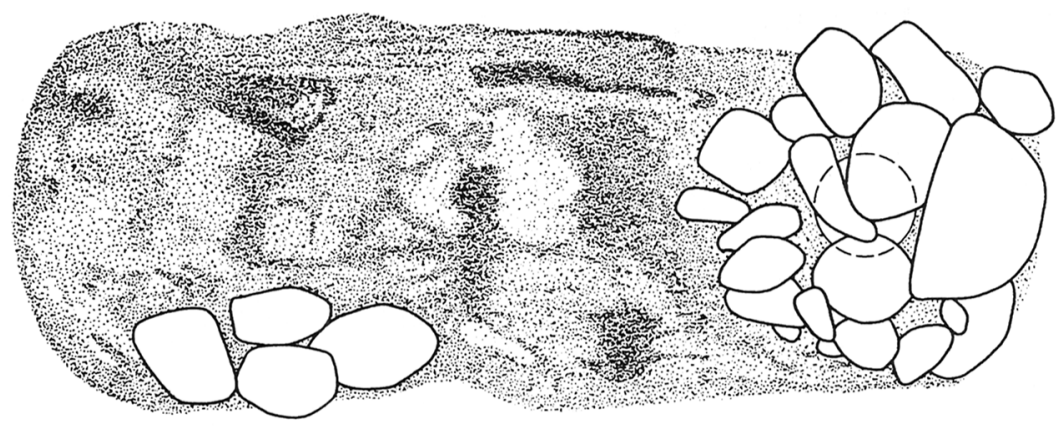

$N$

a

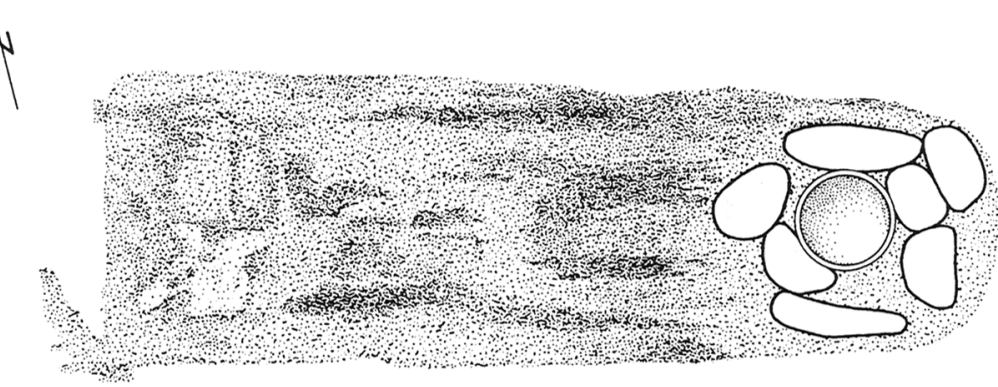

b

\section{feiner Sand mit Holzkohle}

0

$0,5 \mathrm{~m}$

Fig. 32. Gravfund fra Wenningstedt, Altkreis Süddtondern, Sylt. (Efter Aner \& Kersten 1973-1990 bd. 5). Grave from Wenningstedt, Altkreis Südtondern, Sylt. (After Aner \& Kersten, 1973-1990 vol. 5).

le, spandformet lerkar med en vandret knop, fandtes brændte knogler iblandet små trækulsstykker, og liggende herpå en snoet bronzehalsring med kroglukke, der daterer graven til per. III. Under urnens bund og ved dens sider fandtes også brændte knogler, men ifølge beskrivelsen fandtes ingen brændte knogler mellem trækulsstykkerne i gruben (17).

\section{Diskussion}

De to grave fremhæves af Kersten \& La Baume $(1958,56)$ som repræsentanter for en særlig gravform, som der ikke gives andre eksempler på.

For Keitumgravens vedkommende nævnes udtrykkelig, at grubens bund er rødbrændt, hvorimod noget sådant ikke nævnes ved Wenningstedt. Her op-fattes trækullet af udgraveren som nedsmidt i graven. Beskrivelsen af, hvordan de største - og dermed dårligst forbrændte - stykker ligger lige over gravbunden stemmer dog godt overens med ligbålsresterne ved Damsgård, og fænomenet genfindes ved et moderne ligbrændingsforsøg (se nedenfor). Et andet påfaldende træk er, at der ikke i de to eksempler fra Sild er fundet brændte ben mellem trækullet. Dette kan skyldes, at de brændte ben vil ligge koncentreret øverst i bålresterne og kan være opsamlede. 
Til trods for disse usikkerhedsmomenter, som må påregnes, når gamle fundbeskrivelser skal ses i lyset af nye fund, opfattes de to grave fra Sild her som nære paralleller til de samtidige thylandske ligbrændingsgruber. At der netop ved bronzealderens midte har hersket tætte kulturforbindelser mellem de to egne, er tidligere blevet påvist (Kersten \& La Baume 1958, 47, 54; Olsen 1992, 150).

\section{Ligbrondingsgruber}

I de senere år er fra Fyn fremlagt flere eksempler på ligbrændingspladser fra yngre bronzealder (Madsen \& Thrane 1992). I ældre bronzealder har ligbrændingspladser derimod glimret ved deres fravær til trods for den store mængde af brandgrave fra per. III. Med de syv fund, der her er fremlagt - fem fra Thy og to fra Sild - er der for første gang rådet bod på denne fundtomhed (18).

De fremlagte grave udviser mange indbyrdes forskelle, men ét har de tilfælles: Ved dem alle har ligbålet været anlagt i en lav, fladbundet grube.

Ældre beskrivelser af ligbrændinger forskellige steder på jorden viser, at ligbål anlagt i eller over en lav grube er et meget almindeligt fænomen (Wahl \& Wahl 1983, 515). Grubens funktion kan dels være at sikre en bedre forbrænding gennem lufttilførsel nedefra, dels at fungere som opsamlingssted for bålresterne. Den sidste funktion er klart demonstreret ved Damsgård, hvor der stort set ikke fandtes bålrester uden for gruben.

På Hollufgård på Fyn er der foretaget flere forsøg med ligbrænding, bl.a. i grube (Henriksen 1993). En efterfølgende udgravning af den tildækkede ligbrændingsgrube viste øverst tilbagekastet undergrundsmateriale fra opgravningen og derunder et lag med aske og mange trækulstykker med mange brændte ben samt gravgaver. Nederst i gruben fandtes næsten udelukkende trækul, generelt i større stykker end længere oppe, vidnende om en mere ufuldstændig forbrænding. Kun allerøverst i dette trækulslag fandtes enkelte stykker brændte ben. Ligheden med Damsgårdgruben og gruben ved Wenningstedt er iøjnefaldende. Også ved ligbrændingsforsøget var ligbålsresterne lige som ved Damsgård stort set begrænset til gruben.

Ved ligbrændingsforsøget på Hollufgård anvendtes efter paralleller i fynske fund fra yngre bronzealder nedbankede pæle til at holde sammen på bålet. Dette fænomen er ikke påvist ved de her fremlagte grave.

Et særligt træk ved Damsgård, og muligvis også ved Nørhå- og Villerupgravene, er anvendelsen af tørv som brændsel. Dette må formodes at afspejle vanskeligheden ved at skaffe tilstrækkeligt med træ i det åbne thylandske landskab et fænomen, der også er påvist i bopladssammenhæng (Bech 1991, 44ff). Problemer med at skaffe brændsel til ligbålet er velkendte i mange af de egne, hvor ligbrænding har været praktiseret i nyere tid eller stadig praktiseres (Wahl \& Wahl 1983, 516).

\section{Afslutning}

Blandt de her fremlagte fund af ligbrændingsgruber står Damsgårdfundet klarest og med flest facetter, takket være usædvanlig gode bevaringsforhold, en noget skødesløs fremgangsmåde ved opsamlingen af ligresterne forud for gravlæggelsen samt det faktum, at kisten her er placeret uden for selve gruben, hvorved denne stort set er uforstyrret. 


\begin{tabular}{|c|c|c|c|c|}
\hline $\begin{array}{l}\text { Oprindelse } \\
\text { Dybde, cm }\end{array}$ & $\begin{array}{r}\text { jordbund } \\
8-10\end{array}$ & $\begin{array}{r}\text { jord- } \\
\text { bund } \\
0-2\end{array}$ & højfyld & højfyld \\
\hline Analyse nr. & 1 & 2 & 3 & 4 \\
\hline Pollensum, P & 142 & 150 & 175 & 139 \\
\hline Træpollensum, AP & 17 & 16 & 15 & 4 \\
\hline Træer, \% P & 12,0 & 10,7 & 8,6 & 2,9 \\
\hline Urtepollen, NAP & 125 & 134 & 160 & 135 \\
\hline Bar jord, \% NAP & - & 4,5 & 1,9 & 0,7 \\
\hline $\begin{array}{l}\text { Byg type } \\
\text { Havre type } \\
\text { Salturter }\end{array}$ & $\begin{array}{l}- \\
- \\
-\end{array}$ & $\begin{array}{l}0,7 \\
1,5 \\
2,2 \\
\end{array}$ & $\begin{array}{r}1,3 \\
- \\
0,6\end{array}$ & 0,7 \\
\hline Tøreng & 36,0 & 20,1 & 48,8 & 51,9 \\
\hline $\begin{array}{l}\text { Lancetvejbred } \\
\text { Slangetunge } \\
\text { Månerude } \\
\text { Klokkeblomst }\end{array}$ & $\begin{array}{r}34,4 \\
0,8 \\
- \\
0,8 \\
\end{array}$ & $\begin{array}{r}18,7 \\
1,5 \\
- \\
- \\
\end{array}$ & $\begin{array}{r}48,8 \\
- \\
- \\
-\end{array}$ & $\begin{array}{r}51,1 \\
- \\
0,7 \\
-\end{array}$ \\
\hline Vildgræsser & 45,6 & 59,0 & 41,9 & 38,5 \\
\hline Andre urter & 15,2 & 13,4 & 7,5 & 8,1 \\
\hline $\begin{array}{l}\text { Bynke } \\
\text { Røllike type } \\
\text { Brandbæger type } \\
\text { Sandvåner type } \\
\text { Hønsetarm type } \\
\text { Ranunkel } \\
\text { Snerre } \\
\text { Korsblomstrede } \\
\text { Skærmplanter }\end{array}$ & $\begin{array}{r}6,4 \\
- \\
2,4 \\
0,8 \\
0,8 \\
2,4 \\
1,6 \\
- \\
0,8 \\
\end{array}$ & $\begin{array}{r}5,2 \\
1,5 \\
4,5 \\
6,7 \\
- \\
- \\
1,5 \\
- \\
- \\
\end{array}$ & $\begin{array}{r}0,6 \\
2,5 \\
- \\
1,9 \\
- \\
- \\
1,9 \\
0,6 \\
-\end{array}$ & $\begin{array}{r}1,5 \\
2,2 \\
2,2 \\
- \\
- \\
- \\
- \\
2,2 \\
-\end{array}$ \\
\hline Skov og krat & 3,2 & 2,2 & - & 0,7 \\
\hline $\begin{array}{l}\text { Egebregne } \\
\text { Ørnebregne }\end{array}$ & $\begin{array}{l}1,6 \\
1,6\end{array}$ & $\begin{array}{l}1,5 \\
0,7\end{array}$ & - & $0, \overline{7}$ \\
\hline Moser & - & 0,7 & - & - \\
\hline Star & - & 0,7 & - & - \\
\hline $\begin{array}{l}\text { Tungeblomstrede, \% P } \\
\text { Mangeløv }\end{array}$ & $\begin{array}{r}14,8 \\
3,5 \\
\end{array}$ & $\begin{array}{r}10,7 \\
1,3 \\
\end{array}$ & $\begin{array}{l}5,1 \\
4,6 \\
\end{array}$ & $\begin{array}{l}5,0 \\
7,2 \\
\end{array}$ \\
\hline Antal taxa & 15 & 16 & 11 & 11 \\
\hline
\end{tabular}

\begin{tabular}{|l|r|}
\hline Lokalitet & Damsgaard \\
\hline Analyse nr. & $1-4$ \\
\hline Træpollen, AP & 52 \\
\hline Lind & 13,6 \\
Hassel & 37,3 \\
Birk & 16,9 \\
El & 32,2 \\
\hline
\end{tabular}

Fig. 33a. Træpollen.

Tree pollen.

Fig. 33a-b. Pollenanalyser fra Damsgård.

Pollen analyses from Damsgård.

Fig. 33b. Urtepollen

Herb pollen.

Eksistensen af seks andre, nogenlunde samtidige fund, alle med ligbrændingsgruber, viser, at Damsgårdfundet ikke er en isoleret foreteelse, men et eksempel på en mere eller mindre vidt udbredt praksis.

Der er dog helt klart ikke tale om en nøje fastlagt ritus, men snarere om variationer over et tema. Ligheder og forskelle i placeringen og udformningen af selve graven går på kryds og tværs af de geografiske forskelle, dog kan der peges på, at stenkister er den overvejende bisættelsesform ved de thylandske fund, mens de ikke ses ved ligbrændingsgruberne på Sild, hvor de dog ellers er meget almindelige. På grund af det meget lille antal fund, som indgår i undersøgelsen, kan der imidlertid ikke drages videre konklusioner af de påviste variationer i gravskikken. 


\title{
Antropologisk undersøgelse af brændte knogler fra THY 2959, Damsgård, Sønderhå sogn sb. nr. 52, Hassing herred, Thisted amt
}

\author{
Af Pia Bennike
}

\section{Stenkisten}

THY 2959x1F: Talrige knoglefragmenter fra det meste af skelettet, ialt ca. 835 gr. Der er mange kraniefragmenter, en kæbedel, få tænder, fragmenter af ryghvirvler, lårben og øvrige lemmeknogler. Desuden en mængde uidentificerbare fragmenter.

Knoglefragmenternes farve varierer særdeles meget. Flere sorte knogler stammer fra et lårben, men der er også enkelte sorte kranieknogler fra området fortil og omkring nakkeregionen. Størstedelen af kraniefragmenterne er hvidlige, men nedadtil mod kraniets basis bliver nakkebenet tiltagende mere sort indvendigt. Desuden er den yderste del af højre øjenbrynsbue temmelig mørkfarvet.

For at få et samlet billede af de identificerbare kranieknogler, blev de limet sammen. Derved fås tre større sammenlimede stykker dækkende tre områder af kraniet, 1) venstre og 2) højre isseben med afgrænsning af sutura sagittalis (midtsømmen) og del af sutura lambdoidea (nakkesømmen mellem nakkeben og de to isseben). 1) og 2) passer sammen. Desuden fås et større område 3) af den nedre del af højre isseben, som går ned til tindingeregionen. Der ses også større fragmenter fra nakkebenet samt fra øvrige dele af kraniet, som blot ikke kan limes på.

En del små kraniestykker fra ligbrændingsgruben (THY 2959x3Æ, jvnf. nedenfor) passer til stykket ved højre tindingeregion. To mindre kraniefragmenter ligeledes fra ligbrændingsgruben (THY 2959x3Ø2 samt x3̊) passer i området, hvor midtsømmen mødes med nakkesømmen (fig. 14).

I både stenkisten og ligbrændingsgruben er fundet tandrødder. En af stenkistens tandrødder fra en fortand i overkæben er sortfarvet, mens de øvrige (ialt 4) er hvidlige. I stenkisten var der endvidere to mindre kæbefragmenter. Det ene er meget sort, det andet hvidligt. Kæbedelene bærer intet præg af tandtab.

\section{Ligbrandingsgruben}

Fra ligbrændingsgruben foreligger ialt ca. 295 gr. brændte knogler optaget under forskellige fundnumre afhængig af deres placering i gruben (jvnf. fig. 15). Fundnumre kun indeholdende ubestemmelige småfragmenter er ikke anført nedenfor.

THY 2959x3I: Små kraniefragmenter, fragment fra større lemmeknogle, meget små fragmenter fra hvirvel. Fra nordvestlige del af gruben.

THY 2959x3N (fig. 15,8): Slagger. Tåknogle.

THY 2959x3O1 (fig. 15,9): Knoglefragmenter hovedsagelig fra fødder: mellemfodsknogler og enkelte fragmenter fra tåknogler. Desuden fragmenter fra lemmeknogler, f. eks. fra skinneben og lægben.

THY 2959x3P (fig. 15,9): Talrige småfragmenter, blandt andet et fragment af en tåknogle.

THY 2959x3S (fig. 15,7): Talrige småfragmenter, et enkelt fra kraniet, de øvrige fra mindre lemmeknogler for eksempel fra underarme.

THY 2959x3Z1 (fig. 15,6): Småfragmenter, flere fra mindre lemmeknogler samt evt. fra hvirvler. Enkelte er måske ikke fra menneske? 
THY 2959x3Æ1 (fig. 15,1): 6 kraniefragmenter, som kan limes sammen. Hele stykket hører desuden til det højre sammenlimede isseben med tindingeregion fra stenkisten.

THY 2959x3Ø2 (fig. 15,5): Småfragmenter, heriblandt enkelte kraniefragmenter. To kan limes sammen og passer sammen med sammenlimede kraniefragmenter fra stenkisten (venstre nakkeregion).

THY 2959x3A (fig. 15,4): Få fragmenter fra kraniet. To små fragmenter kan limes sammen og passer til de sammenlimede kraniefragmenter fra stenkisten. Kraniestykket stammer fra den øverste og midterste del af nakkebenet.

THY 2959x4A2 (fig. 15,3): Enkelte kraniefragmenter, fragmenter fra en større lemmeknogle samt rødder (hvidlige) fra to énrodede tænder.

THY 2959x4B1 (fig. 15,2): Enkelte småfragmenter. Blandt andet et fragment fra en hvirvel.

\section{Konklusion}

I tre tilfælde var det muligt at afgøre, at brændte knoglefragmenter fra ligbrændingsgruben hører til det brændte knoglemateriale fra stenkisten. Da der i det forholdsvis store materiale ikke er nogen overlappende knogler, kan vi yderligere med stor sandsynlighed slutte, at der kun er tale om brændte knoglefragmenter fra én person. Der er desuden knogler fra et eller flere dyr. Ifølge personlig meddelelse fra Knud Rosenlund, Zoologisk Museum, har disse knogler ikke kunnet artsbestemmes.

Alder- og konsbestermmelse

Det venstre isseben har fordybninger ved midtsømmen på indersiden (lamina interna), som skyldes tryk fra mindre aneurismer (udposninger af blodkar). Det er ikke et usædvanligt fund, men ses sjældent hos helt unge mennesker. Kraniesømmene viser ingen tegn på begyndende sammenvoksning, og vi må derfor formode, at der er tale om en voksen, yngre person, dog næppe under 25 år. En alder på 25-35 år forekommer mest sandsynlig. At der er tale om en yngre person bekræeftes ved, at der ingen slidgigt ses i de bevarede led og hvirvler.

Personens køn er mere vanskelig at afgøre. Lemmeknoglernes tykkelse tyder meget stærkt på en mand. Andre dele derimod, for eksempel en hvirveldel fra 2. halshvirvel samt flere fodknogler forekommer ret spinkle. De sidstnævnte er imidlertid hårdt brændte og kan være skrumpet op til $20 \%$. Hvis det er tilfældet, kan der være tale om resterne fra en mand. Det skal dog tilføjes, at denne bestemmelse er forbundet med en del usikkerhed.

\section{Brandingstemperatur}

For at afgøre om der stadig var organisk materiale (collagen) i de sortbrændte knogler fra lårbenet blev en prøve fra THY 2959x1F undersøgt for organisk/uorganisk indhold med en såkaldt dual foton absorptiometriscanner (som blandt andet bruges til at måle ældre kvinders kalkindhold med henblik på risiko for knoglebrud). Her viste det sig, at der var $8,5 \%$ organisk materiale tilbage. Det vil sige, at brændingen ikke har været fuldstændig, det vil sige mellem $400^{\circ}$ og $600^{\circ}$. Hvordan liget har ligget på ligbålet er vanskeligt at udtale sig om, ligesom der heller ikke er nogen umiddelbar forklaring på, hvorfor en kæbedel og en tand er sortbrændt, mens en anden kæbedel og de øvrige tænder er hvide og derfor brændt ved en højere temperatur. 


\section{Undersøgelse af trækul m.v. fra ligbrændingsgruben ved Damsgård*}

\section{Af KJELd Christensen}

Fra gruben er indsendt fire prøver af trækul m.v. med ønske om bestemmelse af træart samt vurdering af, hvorvidt der er tale om ved fra grene eller stammer.

Undersøgelsen viser, at prøverne hovedsagligt består af trækul, tildels i usædvanligt store stykker. Langt størstedelen af trækullet i alle fire prøver er Fraxinus sp., ask (ialt 90 bestemte stk.). Herudover forekommer der i alle prøverne en mindre mængde trækul af Populus sp. (ialt 18 bestemte stk.), givetvis den eneste "indfødte" danske art, Populus tremula L., bævreasp. Andre træarter er ikke påvist.

En nærmere analyse af aske-trækullet viser, at der er tale om grenved; dette fremgår af årringenes krumning, af vårkarrenes ringe størrelse samt af de generelt meget smalle årringe (jvnf. nedenfor), hvis bredde aftager hurtigt fra marv mod bark. De fleste trækulstykker synes at stamme fra grene med en diameter på 5-10 cm (min. $4 \mathrm{~cm}$, max. $13 \mathrm{~cm}$ for de undersøgte stykker). Disse tal må dog tages med et vist forbehold; der er ikke påvist bark på nogen af prøverne, og asketræs tendens til ringskøre (spaltning parallelt med årringgrænserne) gør det vanskeligt at bestemme den oprindelige diameter med fuldstændig sikkerhed. Trækullet af bævreasp stammer formentlig fra grene af tilsvarende størrelse; for denne træart er det dog vanskeligere at skelne mellem gren- og stammeved end for asketræ.

På enkelte stykker trækul af ask kan tælles mere end 50 årringe, hvis bredder varierer fra mindre end $0,1 \mathrm{~mm}$ til ca. $2 \mathrm{~mm}$. Den gennemsnitlige årringbredde, bestemt på 22 stk. aske-trækul, er 0,6 mm; normalt stammeved af ask har ofte en gennemsnitlig årringbredde på 2-4 mm (jvnf. f.eks. asketræer fra Vallø, NNU j. nr. A 6095). For en umiddelbar betragtning viser årringforløbet ingen tegn på anormale vækstforhold, men det er ikke udelukket, at en egentlig årringanalyse (som dog vil være meget tidskrævende), vil kunne give interessante resultater. Trækullet af bævreasp har meget færre årringe (indtil 14 på de undersøgte stykker), som er væsentlig bredere (i gennemsnit 2,3 mm; min. $0,8 \mathrm{~mm}$, max. $4,4 \mathrm{~mm}$ for de undersøgte stykker) end på aske-trækullet.

Foruden trækul indeholder prøverne enkelte andre bestanddele. Mest fremtrædende er klumper af opblæret, slaggeagtigt materiale med blanke, metalskinnende brudflader. I nogle tilfælde forekommer disse "slagger" alene, $\mathrm{i}$ andre optræder de som "belægning" på trækulsstykkerne - i så fald oftest på skrå brudflader (dvs. uden forbindelse med træets "naturlige« spalteretninger), og med skarp overgang fra slagge til trækul. Dette slaggeagtige materiales oprindelse er uvis (jvnf. dog nedenfor s. 191).

Herudover indeholder i hvert fald nogle af prøverne klumper af forkullet, findelt plantemateriale - muligvis forkullet tørv.

Endelig indeholder samtlige prøver enkelte klumper af ler samt mindre mængder af ler og sand.

*Let revideret uddrag af intern rapport, aftrykt i sin helhed i Robinson \& Christensen 1995 


\title{
Plantemakrofossilanalyse af materiale fra brandlaget $i$ ligbrændingsgruben ved Damsgård
}

\author{
Af David Earle Robinson
}

Ved den arkæologiske udgravning af ligbrændingsgruben fremkom et brandlag nederst $i$ gruben. Laget bestod af en blanding af aske, trækul og større mængder af et finkornet sort materiale, der lå nederst i brandlaget, og som under udgravningen blev tolket som dårligt forbrændte mosetørv (jvnf. ovenfor fig. 7b lag 5 samt fig. 13). Prøver af den formodede brændte tørv blev indsendt til Nationalmuseet til bestemmelse. Formålet med undersøgelsen var at afgøre, om det drejede sig om mosetørv, der var brugt som brændsel og i bekræftende fald fastslå, hvorfra tørven stammede. Ialt blev der indsendt syv prøver af det tørveagtige materiale til makrofossilanalyse. Analysemetoden samt analyseresultatet beskrives i Robinson \& Christensen (1995), hvorfra der her præsenteres et resumé.

\section{Brandlagets sammensatning}

Hovedkomponenten i samtlige prøver var det finkornede sorte materiale, som er nævnt ovenfor. Materialet er undersøgt under mikroskop, og det viste sig at bestå af klumper af findelt plantemateriale med en svag lagdelt struktur. Nogle af klumperne var kun svagt varmepåvirkede, og som konsekvens deraf fremtrådte de mere lysebrune end sorte i farven. Prøvematerialet indeholdt også frø, frugter og andre plantemakrofossiler, fragmenter af trækul, aske (rødlig, grålig eller brunlig i farven) samt sand, småsten og slaggeagtigt materiale med blank eller mat overflade.

Det findelte plantemateriale var velbevaret og i det meste ikke særligt omdannet, inden det blev forkullet. Dog var der enkelte forkullede klumper, hvor det var svært eller ligefrem umuligt at ane struktur efter plantemateriale. Undersøgelsen viser, at det tilsyneladende fortrinsvis består af bladfragmenter af enkimbladplanter, sandsynligvis græsser eller halvgræsser.

Frø, frugter og andre plantemakrofossiler var tilstede i ringe omfang i samtlige prøver. Kun en enkelt prøve indeholdt mange frø. Hovedparten var velbevarede og viste ingen tegn efter skader eller særlig nedbrydning. Hyppigst i brandlaget var frø af Sieglingia decumbens (Tandbælg), Carex sp (arter af Star) og Potentilla erecta (Tormentil). Herudover var der enkelte frø af Batrachium sp (VandRanunkel), Chenopodium sp (Gåsefod), cfr. Lotus uliginosus (cfr. Sump-/Klit-Kællingetand), Lychnis flos-cuculi (Træulekrone), Myrica gale (Pors), Pedicularis sylvatica (Mose Troldurt), Poaceae (Græsser), Veronica sp (Ærenpris) og Viola sp (Viol).

Brandlaget indeholdt også en del forkullede jordstængler af Potentilla erecta (Tormentil) samt bladbaser og blade af Sieglingia decumbens (Tandbælg). Herudover var der enkelte kviste af Calluna vulgaris (Hedelyng), blade af Erica tetralix (Klokkelyng), den nederste del af en blomst fra et medlem af Lyngfamilien samt et skud af en mos Hypnum cupressiforme.

Alle de bestemte planterester er fra arter, der hører hjemme i jyske hedemoser, bortset fra frøet af Chenopodium sp, som sandsynligvis stammer fra en ukrudtsplante.

Som nævnt tidligere er der også fundet klumper af slaggeagtigt materiale, især i prøve THY 2959x3T. Nogle klumper var sorte og blanke, næsten glasagtige i udseende; andre havde en mat og finrynket overflade. Disse klumper tolkes foreløbigt som delvis forbrændte fragmenter af kød og hud. Et lignende materiale er beskrevet af Wells (1960) i en artikel om ligbrænding. Han foreslår, at materialet muligvis stammer fra keratin i håret, men dette virker usandsynligt.

Tolkning og diskussion

Både sammensætningen og stratigrafien af brandlaget er kompliceret. Dette er ikke overraskende i lyset af den handling, der er foregået i gruben. Ligesom mængden af forskellige materialer, som 
er indblandet, har betydning. Her tænkes på optændingsmateriale, brændsel og gravgaver samt selvfølgelig selve liget med eventuelle madrester i tarmene, tøj o.l.

Det er dog hovedkomponenten i brandlaget - det finkornede sorte materiale - som denne beretning beskæftiger sig med. Materialet er tilstede i sådan en mængde, at der må være tale om brændsel til ligbålet. På grundlag af analyseresultatet, som er fremlagt her, er det mest nærliggende at tolke materialet som brændte rester af hedemosetørv.

Der findes dog en anden mulighed, som det er nødvendigt at undersøge. Brændselsmaterialet kan være gødning, som stammer fra husdyr (køer, heste, geder eller får), der har græsset på hedemosearealer. I træfattige egne har man gjort omfattende brug af gødning som brændsel både $\mathrm{i}$ fortid og nutid. Pollenanalyse viser, at Thy var et meget skovfattigt område i bronzealderen (Andersen 1995), og det er måske lige så sandsynligt, at man indsamlede gødning til brændsel, som at der blev gravet tørv til formålet.

Der er derfor foretaget undersøgelser af recente prøver af brændt og ubrændt tørv og kogødning fra Thy. Det viste sig, at der er mange ligheder imellem de to materialer. Begge består af findelt plantemateriale $i$ en nedbrudt grundmasse, og begge kan være lagdelt. Begge kan også indeholde fint og groft sand og giver en hvidlig/grålig aske, når de er fuldstændig brændt (dog plejer tørv at give aske med et mere rødligt eller brunligt skær (jvnf. asken i ligbrændingsgruben fra Damsgård)). Både tørv og gødning kan indeholde velbevarede uskadte frø og frugter, men som regel er de enten knuste, knækkede eller på anden måde nedbrudte i gødning. Til gengæld er der klare forskelle med hensyn til indholdet af grus og småsten samt af bladbaser og jordstængler af f.eks. tandbælg og tormentil. Det førstnævnte findes i de nederste tørvelag lige over mineralbunden. Det sidstnævnte er en del af den levende vegetation og findes i de øverste $2-5 \mathrm{~cm}$ af tørven. Ingen af delene findes i gødning fra de tidligere nævnte husdyr.

Alt $\mathrm{i}$ alt viser undersøgelsen af brandlaget, at der er anvendt tørv fra en hedemose - og ikke gødning fra husdyr - som brændsel til ligbålet.

Ifølge Becker (1948) og Hove (1983) stammer de ældste arkæologiske beviser for tørvegravning fra førromersk jernalder. I lyset af resultatet af denne undersøgelse af materialet fra Damsgård (dateret til ældre bronzealder per. III) skal vi nu kigge meget længere tilbage efter de første spor af denne praksis. 


\title{
Pollenanalyse af jordprøver udtaget af profil tværs over højen ved Damsgård
}

\author{
Af Svend Th. Andersen
}

Pollenprover

P1 + P2: Udtaget fra det gamle muldlag under gravhøjen (fig. 6 lag 4). P1 (fig. 33b analyse nr. 1): $8-10 \mathrm{~cm}$ under muldlagets overflade. P2 (fig. $33 \mathrm{~b}$ analyse $\mathrm{nr} .2$ ): $0-2 \mathrm{~cm}$ under muldlagets overflade. P3 + P4 (fig. 33b analyse nr. 3 og 4): Udtaget fra højfyld (fig. 6 lag 2).

Resultater af pollenanalyser (junf. fig. 33a-b)

Trapollen: Træpollenindholdet er lavt (3-12\%) og området har været skovløst. Hassel og el var fremherskende (37 og 32\%). Træpollenet stammer sandsynligvis fra tidligere bevoksninger af kulturpåvirket kratskov.

Urtepollen: Lancetvejbred udgør 19-34\% i jordbunden og er meget hyppig i højfylden (49-52\%). Moderat til stærkt græsningstryk er angivet. Planter fra bar jord er sjældne, og andre urter, især bynke, er forholdsvis hyppig i højfylden. Forekomst af kornpollen (byg og havre type) $\mathrm{i}$ analyse nr. 2 kan tyde på tidligere dyrkning.

Konklusion

Gravhøjen er anlagt i et område med husdyrgræsning af noget varierende styrke. 


\section{NOTER}

1) Højen har sb. nr. 52 i Sønderhå sogn, Hassing herred, gl. Thisted Amt. Jour. nr. THY 2959.

2) Sb. nr. 47, Sønderhå sogn. NM B 1718 m.fl.

3) Sb. nr. 60, Sønderhå sogn. NM B 8436-37.

4) Undersøgelsen blev i 1992 foretaget af Anne-Louise Haack Olsen og Jens-Henrik Bech med økonomisk støtte fra Rigsantikvarens Arkæologiske Sekretariat. I 1993 blev udgravningen som led i Thy projektet (jvnf. Bech 1993) støttet af Statens Humanistiske Forskningsråd samt midler fra National Science Foundation, USA (grant * SBR-9207082). Foruden Jens-Henrik Bech deltog Timothy Earle, Deborah Erdmann, Mads Ravn og Peter Aperlo.

5) Som parallel kan henvises til en per. III kvindegrav på Sild: Aner \& Kersten 1973-1990, bd. 5, grav nr. 2737. Graven, der var en brandgrav i en stenkiste, indeholdt en fibula med korsformet hoved, en armring med omløbende vulste, 2 små bronzespiralringe og en snoet halsring af bronze, samt 2 fragmenter af knoglenåle og et lille lerkar.

6) Den forromerske tørvegravning ved Nørre Smedeby (Becker 1948) er foregåt $i$ en mose med et op til 2 m tykt lag sphagnumtørv, hvor man øjensynlig har fremstillet æltetørv (Hove 1983, 41). I modsætning hertil er tørvene fra Damsgård gravet et sted, hvor tørvelaget givetvis har været relativt tyndt. Den anvendte tørvegravningmetode kan derfor have været nært beslægtet med den teknik, som anvendtes ved gravning af overfladetørv til højbygning.

7) Mundtlig oplysning fra Sv. Th. Andersen. Jvnf. Ødum 1980, $198 f$.

8) Jour. nr. THY 1550. Hundborg herred, gl. Thisted Amt. Beretning i Museet for Thy og V. Hanherred. Udgravningsleder var Anne-Louise Haack Olsen.

9) Grav 1 var en skeletgrav af Egtvedtype med brændte knogler, antagelig fra et barn, ved fodenden. Grav 2 er den her omhandlede grav. Grav 3 var en lille stenkiste med brændte ben, og grav 4 en næsten bortpløjet urnegrav.

10) Knoglerne er analyseret af Pia Bennike, Antropologisk Laboratorium.

11) Jour. nr. THY 1696. Refs herred, gl. Thisted Amt. Beretning i Museet for Thy og V. Hanherred. Undersøgelsen blev i 1981 forestået af Jakob Vedsted og i 1982 videreført af Per Orla Thomsen. Begge takkes for tilladelse til publicering af fundet.

12) Ud over de her beskrevne grave, der tilhørte den 1. og 2. højfase, fandtes en stenkiste (grav 4) fra per. III med sværd, dobbeltknap, stangnål og brændte ben, tilhørende 3. højfase, en stenkiste (grav 5) ligeledes fra per. III med 2 bronzearmringe og en bennål samt brændte ben, tilhørende 4. højfase, og en stenkiste (grav 6), antagelig ligeledes fra per. III, med en bennål samt brændte ben, tilhørende den 5 . højfase.

13) Jvnf. eksempelvis Aner \& Kersten 1973-1990, bd. 1, grav 460 og bd. 7 grav 3378.

14) Knoglerne er analyseret af Tine Trolle-Lassen.

15) Knoglerne er analyseret af Pia Bennike, Antropologisk Laboratorium..

16) Aner \& Kersten 1973-1990. De to grave er endvidere beskrevet i Kersten \& La Baume 1958. Se nedenfor note 17.

17) Fundet er beskrevet to gange i litteraturen dels med en grundig omtale i Kersten \& La Baume 1958 (NFI) s. 429-430 og s. 597-598 og dels, mere kortfattet, hos Aner \& Kersten 1973-1990, bd. 5 s. 135. De to beskrivelser stemmer ikke overens, hvad angår forholdet mellem urnen og gruben. I NFI lyder beskrivelsen: "Efter at man havde bisat urnen i østenden af gruben, fyldte man denne med små og store trækulstykker" (forf. oversættelse). Graven opfattes her tydeligvis som en enhed (se også anf. arb. s. 56). Hos Aner \& Kersten 1973-1990, tolkes urnen derimod som sekundært nedsat i en skeletgrav med en forsvundet trækiste (s. 135). Der er intet i beskrivelsen, der støtter denne tolkning, som ligner en efterrationalisering baseret på grubens overfladiske lighed med et kisteleje. Her anses gruben og urnen for at være samhørende.

18) I Aner \& Kersten 1973-1990, er dog enkelte steder, bl.a. bd. 4 s. 78ff, beskrevet brandlag med brændte knogler fra ældre bronzealder.

\section{LITTERATUR}

Andersen, Sv. Th. 1994: Geobotaniske Undersøgelser af Kulturlandskabets Historie. Pollenanalyser fra gravhøje og søer i 1993. DGU Kunderapport 18, 1994.

Andersen, Sv. Th. 1995: Pollen Analyses from Early Bronze Age Barrows in Thy. Journal of Danish Archaeol$o g y$ (in press).

Aner, E. \& K. Kersten. 1973-1990: Die Funde der älteren Bronzezeit des nordischen Kreises in Dänemark, Schleswig-Holstein und Niedersachsen. Bd. 1-9.

Bech, J-H. 1991: Et bronzealderlandskab ved Bjerre i Nordthy. MIV 16, 1991, s. 41-48.

Bech, J-H. 1993: Thy-projektet: Et nyt geobotanisk/kulturhistorisk forskningsprojekt i det vestlige Limfjordsområde. Limfjordsprojektet, rapport nr. 6, 1993, s. 53-62.

Becker, C.J. 1948: Tørvegravning i ældre jernalder. Fra Nationalmuseets Arbejdsmark 1948, s. 92-100.

Broholm, H.C. 1944: Danmarks Bronzealder bd. II.

Broholm, H.C. 1949: Danmarks Bronzealder bd. IV. 
Broholm, H.C. 1952: Danske Oldsager, bd. III: Aldre Bronzealder.

Henriksen, M.B. 1993: Et ligbrændingsforsøg på Hollufgård. Fynske Minder 1993, s. 99-116.

Hove, Th.Th. 1983: Torvegravning i Danmark. Fra håndgravning til moseindustri. Udvikling og vilkår. Under redaktion af $\mathrm{G}$. Lerche.

Kersten, K. \& P. La Baume. 1958: Vorgeschichte der Nordfriesischen Inseln.

Madsen, C. \& H. Thrane. 1992: Udgravninger af sydfynske gravhøje fra yngre bronzealder. Fynske Minder 1992, s. 23-42.

McKinley, J.I. 1994: A pyre and grave goods in British cremation burials; have we missed something? Antiquity 68, 1994, s. 132-134.

Olsen, A.-L. H. 1992: Egshvile - A Bronze Age Barrow with Early Urn Graves from Thy. Journal of Danish Archaeology 1990, s. 133-152.

Rasmussen, M. 1993: Bopladskeramik i aldre bronzealder. Jysk Arkæologisk Selskabs skrifter, XXIX, 1993.

Robinson, D.E. \& K. Christensen. 1995: Plantemakrofossil- og vedanatomisk analyse af materiale fra en ligbrændingsgrube ved Damsgård, Sønderhå sogn, Hassing herred, Thisted amt. THY 2959, NNU j.nr. A 7496. NNU rapport nr. 2, 1995. København, Nationalmuseet.

Wahl, J. 1982: Leichenbranduntersuchungen. Ein Überblick über die Bearbeitung und Aussagemöglichkeiten von Brandgräbern. Prähistorische Zeitschrift bd. 57, 1982.

Wahl, J. \& S. 1983: Zur Technik der Leichenverbrennung. 1: Verbrennungsplätze aus archäologischen Quellen. Archäologisches Korrespondenzblatt 13, 1983, s. 513-520.

Wells, C. 1960: A study of cremation. Antiquity XXXIV, s. 29-37.

Ødum, S. 1980: De vildtvoksende træer og buske. Danmarks Natur bd. 6. Skovene. 1980, s. $143 \mathrm{ff}$. 


\section{Damsgård}

\section{A ploughed-over barrow from Early Bronze Age Per. III with stone cist and pyre-pit}

At the site of 1)amsgard, Thy, in the north western part of Jutland (fig. 1), an Early Bronze Age cremation burial with the remains of the actual pyre has been excavated in a ploughed-over barrow. Similar finds from Thy and the island of Sylt show that this is not an isolated phenomenon and confirm earlier evidence of cultural connections between the two areas.

\section{Damsgård}

The 1)ansgaird barrow was situated on a ridge, $1 \mathrm{~km}$ broad, bordered to the east, south and west by meadows and bogs (fig. 2). The barrow had two phases and achieved a maximum diameter of $15 \mathrm{~m}$ (fig. 5). Apart from a small secondary grave from the Late Iron Age, only the primary grave was preserved. This was a stone cist, oriented ESE-WNW, measuring (). $2 \times() .7 \mathrm{~m}$ internally and (). $3 \mathrm{~m}$ deep. The cist was located south of the centre of the barrow, and immediately to the north of it was a shallow pit (fig. 3 and $7 \mathrm{a}-\mathrm{b})$, measuring $2.8 \times 1.2 \mathrm{~m}$ and ().28 $m$ deep, oriented NE-SW with the northern end lying directly in the centre of the barrow.

The cist contained cremated bones together with a bronze fibula, a small bronze knife and a plain bone pin (fig. $8 \mathrm{a}-\mathrm{c}$ ). (On top of the bones and grave goods was a $2 \mathrm{~cm}$ layer of yellowish ash containing charcoal.

The pit also contained ash, mostly of a reddish and yellowish colour with large whitishgrey patches, together with charcoal, cremated bones and two bronze objects. At the northern end there were fragments of the cranium, and at the southern end fragments of bones from the legs and feet. In the middle there was a bronze armring with a fragment of a limbbone, presumably from the arm, adhering to the inner side (fig. 8d). Close to the arm-ring there was a small bronze spiral, probably a finger ring (fig. 8e). At the bottom and along the sides of the pit, below the ash-layer, there was a compact layer of black, charred organic material, interpreted as poorly-burnt peat (fig. $10-13)$
Analysis of the cremated bones from the cist and the pit, respectively, showed without any doubt that they came from the same person an adult 25-35 years of age - since fragments of the cranium from the cist could be fitted together with fragments from the pit (fig. 14; appendix 1). The grave goods show that the deceased was a woman. The armring, as well as the small bronze spiral and fragments of one or more bone pins (fig. 8f), all from the pit, agree well with the grave goods from the cist, dating both to per. III of the Early Bronze Age.

Analysis of charcoal from the pit shows that most pieces come from branch-wood of ash, with small amounts of aspen. Remains of trunk-wood or of other tree species were not found (appendix 2).

Macrofossil analysis of the black, charred material from the pit showed that it consisted of peat taken from shallow heathland peat deposits and had burned poorly (appendix 3).

Pollen analysis of samples of barrow fill and of the old subsoil beneath the barrow showed that the Early Bronze Age landscape around the barrow had been virtually treeless apart from perhaps some scrub woodland. No pollen from ash or aspen were found, meaning that most of the firewood had been transported over some distance, probably from the wetland areas beyond the ridge on which the barrow was situated. The peat used as fuel probably also came from these areas.

The area around the barrow was mainly used for grazing and a little arable agriculture. The proportion of ribwort plantain-pollen in the barrow fill was greater than in the old subsoil, suggests that the sods for the barrow had been taken from an area that was more heavily grazed than the actual spot where the barrow was erected (appendix 4; Andersen 1995).

The fuel used in the pyre pit from I)amsgard demonstrates the importance of wetlands as a source of fuel in the open Early Bronze Age landscape of Thy. The archaeobotanical analyses of the material from Early Bronze Age per. III at I)ansgard provide us with the earliest archaeological evidence of peat digging for fuel from l)emmark. 


\section{l'arallel finds}

Four other finds from Thy, and two finds from the island of Sylt in the Wadden Sea are interpreted as parallels to the I)ansgaird grave and pyre.

\section{Norha}

At Norhå in central Thy (fig. 1), at the site of a totally obliterated ploughed-over barrow, a stone cist was found measuring $1.1 \times() .4 \mathrm{~m}$ internally and ().25 $\mathrm{m}$ deep (fig. 17a-b). The sole contents were cremated bones. In continu-ation of the cist there was a trough-shaped pit, ().8x().6 $\mathrm{m}$, of which the southern end seems to have been destroyed in the construction of the cist. The pit contained a fill which was both reddish (probable exposure to high temperature) and charred (fig. 18) with a few cremated bones. ()steological analysis showed it likely, but not absolutely certain, that the bones from the cist and the pit come from the same individual - an adult person, probably a woman, 1835 years of age. Among the bones from the pit and the cist were unidentifiable animal bones. The find is interpreted as a pyre and corresponding grave of the same type as the 1)amsgaird find. It can be dated to $c$. per. III of the Early Bronze Age, based on the type and size of the cist.

\section{Villerum}

At Villerup in southern Thy (fig. 1) a partly over-ploughed barrow was excavated which contained 6 graves, of which the three oldest, belonging to the two first phases of the barrow, are also interpreted as parallels to the D)amsgaird find.

Crave 1 , the primary grave, which had been covered with a small mound only $4,1 \mathrm{~m}$ in diameter and ().5 $\mathrm{m}$ high, was a small irregular stone cist, measuring (). $3 \times() .2 \mathrm{~m}$ internally (fig. 21-22). The cist was constructed in the southern end of an oval pit, $1.1 \times() .6 \mathrm{~m}$. The cist contained cremated bones, a fragment of woollen cloth and a bronze tutulus (fig. 23), whereas the pit only contained various layers of organic fill, some with charcoal. At the bottom of the pit, red-burnt patches were seen in the subsoil. The cremated bones in the cist came from an infant 7-13 months old, and the grave can be dated to per. II of the Early Bronze Age on the basis of the tutulus.

Craves 2 and 3 both belonged to the second phase of the barrow, and were probably constructed in per. III of the Early Bronze Age. Crave 2 (fig. 24-26) was an oval pit, 1.() $\times($ ).6 $\mathrm{m}$, the sides and bottom were covered with a thin layer of charcoal beneath a layer of reddish/yellowish, probably burnt, fill. (In the bottom of the pit was a small concentration of cremated bones and an irregular stone-setting with an empty clay vessel (fig. 27). The bones came from an infant 12 months old. Based on stratigraphical evidence, the grave camnot be later than per. III of the Early Bronze Age.

Crave 3 was a stone cist measuring $(0.75 \times() .35 \mathrm{~m}$ internally (fig. 28-3()). It contained cremated bones and a badly preserved bronze fibula. The cist had been constructed in a shallow pit, very similar to the one in grave 2, which it almost totally occupied. Like the latter, it contained a thin, reddish/yellowish, probably burnt layer with charcoal at the bottom and along the sides. By accident, the cremated bones from the grave became mixed with bones from some of the other graves and could therefore not be identified. Based on the fact that all three pits showed traces of fire, they are interpreted as pyre-pits like the one from 1)amsgaird, but unlike the latter, the Villerup pits seem to have been emptied completely before the grave was constructed.

Sylt

On the island of Sylt, two of the numerous graves from the Early Bronze Age show similarities to the graves with pyre-pits from Thy (Aner \& Kersten 1973-199() vol. 5, nos. 27()7 and 2766).

At Keitum, a grave consisting of an oblong pit, was found in a ploughed-over barrow (fig. 31). The pit measured $2.5 \times() .7 \mathrm{~m}$ and the fill was rich in charcoal, especially close to the bottom where red-burnt patches could be seen in the subsoil. At one end of the pit was a pile of cremated bones from an adult, with a bronze finger ring and some sherds. The grave is dated to the Early Bronze Age.

At Wemingstedt a pit of similar dimensions, $2.1 \times() .75 \mathrm{~m}$, was found beneath the surface, between two closely adjacent barrows (fig. 32). The fill was fine, yellowish/brown sand with many pieces of charcoal, up to $1 \mathrm{~m}$ long, the largest lying at the bottom. At one end of the pit stood an urn in a small stone-setting. It contained cremated bones and a thin, twisted neck-ring of bronze with hook-shaped ends, dating the find to per. III of the Early Bronze Age. Both finds are interpreted as pyre-pits containing the actual graves as well as remains of the pyre. 


\section{Prere-pits}

The custom of erecting a pyre in or over a low pit is a geographically widespread phenomenon. At the museum of Hollufgard on Funen, an experiment was carried out where the corpse of a pig was burned on a pyre, erected over a pit dug into the subsoil (Henriksen 1993). Subsequent excavation of the pit showed a stratigraphy very similar to that at 1)amsgard: ()n the bottom there was mainly charred, not properly burned fuel and the upper part comprised ash containing cremated bones. The remains of the pyre after the cremation were almost exclusively confined to the pit.

\section{Conclusion}

The 1)ansgard find, thanks to an excellent state of preservation, can be without any doubt interpreted as the remains of a pyre, erected over a shallow pit, with the stone cist containing the greater part of the bones and gravegoods. The 4 other finds from Thy and the 2 finds from Sylt are likewise interpreted as pyre- pits with the corresponding graves showing, however, a number of different characteristics: Most of the graves from Thy have stone cists or stone-settings, the graves from Sylt have a heap of bones and an urn in a stone-setting respectively. At Villerup, the pits seem to have been emptied, whereas the pits from l)ansgård, Norhå and the two from Sylt contain remains of the pyre. At Villerup and in Sylt the graves are constructed within the pits, whereas the cist at Damsgard is placed outside the pit, and the cist at Norhå has obliterated part of it.

Notwithstanding these differences, the finds of pyre-pits from the Early Bronze Age are seen as evidence of a more or less general practice which so far is known only from Thy and from Sylt. Other evidence from the Early Bronze Age, especially per. III, likewise indicates close contacts between the two areas (Kersten \& La Baume 1958, 47, 54; ()lsen $1992,15())$.

\author{
Amme-Louise Haack ()lse'n \& Jens-Henrik Bech \\ Museet for Thy og Vester Hanherred, \\ DK-77()() Thisted \\ Pia Bennike \\ Kobenhavns Universitet \\ Kjeld Christensen \\ Nationalmuseet \\ David Earle Robinson \\ Nationalmuseet \\ Spend T\%. Andersen \\ Dammarks Cieologiske Undersogelser \\ (Oversattelse (figurtekster): David Earle Robinson
}

